\title{
Britain in the classical world: Samuel Lysons and the art of Roman Britain 1780-1820
}

\author{
Sarah Scott
}

\section{Abstract}

The study shows how the eminent antiquary Samuel Lysons (1763-1819) used his publications of Romano-British remains, which were aimed at a British and Continental audience, to challenge the widely held view that Britain's climate and national characteristics were incompatible with artistic excellence and that Britain was culturally inferior to its Continental neighbours, most notably France, in both past and present. In particular, it shows how he depicted villas and mosaics as some of the finest examples of British cultural achievement under Roman rule, in a period when Roman Britain was largely seen as a military province and cultural backwater, and when aristocratic tastes were predominantly cosmopolitan. He asserted a dramatic improvement from former barbarism and placed Britain firmly within a pan-European classical tradition. The publications also showcased British achievements in the recording of Roman remains and antiquities and in landscape painting, serving as an impressive statement of intellectual and artistic superiority. The study provides a more nuanced understanding of the ways in which 'local' antiquities and topographical painting were employed in the definition and assertion of national identities in this period, and in particular, shows that Samuel Lysons and his associates were at the heart of a social and intellectual elite, working collaboratively to an international agenda, celebrating Britain's cultural leadership in Europe. Their efforts, most notably in the recording of Romano-British mosaics, have underpinned an exemplary tradition of mosaic scholarship in Britain, and merit far greater recognition. 


\section{Introduction}

Aristocratic and antiquarian interest in the Mediterranenan classical past has been extensively researched in recent years. ${ }^{1}$ This body of scholarship shows that Britain was in direct competition with its Continental neighbours in the acquisition of the remains of Mediterranean classical antiquity, and that there was a strong desire to be seen to live up to common European standards in collecting and connoisseurship against the backdrop of a shared classical heritage and growing nationalism in the wake of conflict in Europe; ${ }^{2}$ in particular, there was a concern to challenge the widely held view that Britain was culturally inferior to its Continental neighbours, most notably France. ${ }^{3}$ While a number of studies address the increasing importance of discoveries of Romano-British remains in relation to the construction of nationhood and empire-building, the significant number of impressive volumes on Romano-British art and antiquities produced in this period has not been fully scrutinised and explained; in particular, there has been no evaluation of the ways in which these discoveries were presented and disseminated to a British and Continental audience at a time when access to the Continent was severely restricted and international rivalry in the arts and sciences was intense. For the first time it was becoming clear that Britain had been part of the 'civilised' Roman world, and this provided new opportunities to challenge negative

\footnotetext{
${ }^{1}$ For example, Coltman 2006; Haskell and Penny 1981; Haskell 1993; Dyson 1996; Ayers 1997; Emilia Masci 2007; Kurtz 2000; 2004; Hoock 2007; 2010a and b; Scott 2003.

${ }^{2}$ On travel restrictions due to the Napoleonic Wars (1796-1815) and the impact of this on archaeological interests, see for example, Hingley 2008, 249; Henig and Booth 2000, 213. See also Dyson 2006, 19 for a discussion of the wider context. On growing patriotism and national consciousness, see for example Colley 1992a, particularly 102-47; 1992b; 1986; 1984; Newman 1987; Kidd 1996. On patriotism and the arts in Europe, Craske 1997, 89-144. On the representation of the past in nineteenth-century Britain and France, see Bann 1984.

${ }^{3}$ For negative perceptions of British cultural achievements, see for example Dubos 1719, Le Blanc 1747; Montesquieu 1751; Winckelmann 1765. On negative perceptions of provincial Roman culture and antiquarianism, see for e.g. Essex 1774; Sweet 2004, 163-4. For Walpole's views, see for example Horace Walpole to William Cole, 1 Sept 1778 in Lewis (ed) 1981, ii, 116-17. On artistic achievements as a reflection of national character and civility, and Britain's perceived inability to compete, see Hoock 2003a, 5. On the appeal of French culture, see Newman 1997, 1-20; Eagles 1997. On archaeological and artistic rivalry with the French, see Hoock 2010a and b; 2007 and 2003a, 180-202.
} 
perceptions of Romano-British art and to assert Britain's place within a pan-European classical tradition. ${ }^{4}$

These issues will be addressed through a critical examination of the publications of Samuel Lysons (1763-1819). Lysons was an eminent antiquarian who was recognised nationally as an authority on the remains of Roman Britain; his Woodchester (1797) and Reliquiae Britannico Romanae (1813-17) came to be ranked amongst the most sought-after publications of the day. ${ }^{5}$ This paper will first explore the reasons why Lysons believed it was worthwhile to expend huge effort and expense on these projects, given the risk that the subject matter would not appeal to subscribers with predominantly cosmopolitan tastes. Second, the ways in which the discoveries were presented for a British and Continental audience will be examined and consideration given to how Lysons asserted Britain's place at the heart of a shared classical heritage and British antiquarians at the forefront of archaeological excavation and recording in Britain and Europe. Particular attention will be paid to Lysons' landscape paintings, which he used to directly challenge the notion that Britain's climate and national characteristics were incompatible with artistic excellence and cultural achievement. The impact of these publications on the development of priorities in the study of Romano-British art will be assessed and in particular Lysons' role in the emergence of an exemplary tradition of mosaic scholarship in Britain, and directions for further study will be identified.

\footnotetext{
${ }^{4}$ On Romano-British remains in relation to the construction of nationhood and empire-building, see for example Hingley 2000; 2008; Sweet 2004, 155-88. For the importance of civil interpretations and their elaboration in this period, see Hingley 2008, 169-208.

${ }^{5}$ See Fleming 1934 and Steer 1966 for selected correspondence and social networks. On his role in the Society of Antiquaries, Evans 1956, 231. On his life and achievements, Goodwin (revised by Frith) 2004; Morgan 1886, xxii; Haverfield 1924, 80-81; Henig 1995, 178; Johns 2001; Todd 1996, 100.
} 


\section{Lysons' works and their context}

The collection and publication of classical antiquities had long been an important marker of social status and national identity across Europe ${ }^{6}$ but publications proliferated at a tremendous rate in the wake of the excavations at Herculaneum and Pompeii, and rivalry between European nations intensified. In Britain, the Society of Dilettanti was formed in 1734 by a group of wealthy young English gentlemen; the Society financed numerous archaeological expeditions for 'the public good' and produced a number of influential publications, including James Stuart and Nicholas Revett's The Antiquities of Athens (1762), which established Britain as a leading player in the recording of Mediterranean classical remains. ${ }^{7}$

The Society of Antiquaries was equally active in this period, and was committed to producing publications characterised by scrupulous attention to accuracy. It employed its own draughtsmen from the 1780s, including Charles Alfred Stothard (1786-1817), famous for his Monumental Effigies of Great Britain (1811), ${ }^{8}$ who also assisted Lysons with the recording of villas. ${ }^{9}$ As shown by Nurse, the Society's publications, which included the imperial-folio size Vetusta Monumenta, a series of volumes which included approximately 350 illustrations, published with a view to the preservation of the memory of 'British things', were innovative and exemplary. ${ }^{10}$ Lysons' volumes resembled wellknown publications on Mediterranean classical antiquities in their scale and format but were characterised by an attention to detail, and a genuine belief in the national and international

\footnotetext{
${ }^{6}$ See for e.g. Coltman 2006; Haskell and Penny 1981; Haskell 1993; Dyson 1996; Ayers 1997; Emilia Masci 2007; Kurtz 2000; 2004; Hoock 2007; 2010a and b; Scott 2003.

${ }^{7}$ Stuart and Revett 1762-1816; See Kelly 2009 on the Society of Dilettanti, and in particular chapter 5 on archaeology and identity in the Enlightenment.

${ }^{8}$ Lindley 2012.

${ }^{9}$ Smiles 2007; Lindley 2012.

${ }^{10}$ Nurse 2007, 143.
} 
significance of British antiquities which were undoubtedly influenced by the work of the Society of Antiquaries.

Woodchester (1797) and Reliquiae (1813-17), dedicated to King George III, describe and illustrate the remains of a number of villas and other sites and antiquities (FIGURE 1). ${ }^{11}$ Lysons' archaeological activities attracted significant attention during the Napoleonic wars when access to the continent was severely restricted. ${ }^{12}$ As stressed by Henig, his excavations of a number of substantial Romano-British villas appear to have enjoyed a similar cachet to those in Pompeii and Herculaneum, and afforded an opportunity to discover high-quality works of art when access to the sites of Italy was extremely difficult. ${ }^{13}$ The visitor book for the Bignor excavations has survived, with signatures beginning on 13 October 1814; it shows that large numbers of visitors came not only from Sussex but also from all over Britain, including 'Scotland, Northumberland, Durham, Yorkshire, Lancashire, Staffordshire, Worcestershire, Northamptonshire, Oxfordshire, Wales, Somerset, Cornwall, Hampshire, Surrey, Kent, Essex and Hertfordshire'. The villa attracted approximately 1,300 visitors of all social classes from the beginning of March to the end of November $1815 .{ }^{14}$

Lysons' volumes ranked amongst the finest publications of the day, and copies could be found in the King's library and on the shelves of many other famous private libraries; Woodchester (1797), Bath (1802), Horkstow (1801) and Frampton (1808) are listed in the sale catalogue of Queen Charlotte's Library, which took place in June 1819 under the hammer of Mr Christie; the Woodchester volume 'splendidly bound in Russia, with joints' (handwritten notes suggest a price of f9). In the 1825 Phillip's catalogue relating to the sale of books from the library at Fonthill Abbey in 1804, a Gothic revival house in Wiltshire owned by the enormously wealthy William Thomas

\footnotetext{
${ }^{11}$ For an overview of discoveries in this period and their reception, see Hingley 2008, 169-208. On Lysons' excavations, see Henig 1995, 178; Todd 2004, 448-49; Hingley 2008, 247-54.

${ }^{12}$ See Woodchester (1797) for a list of subscribers. That Lysons was highly esteemed by the royal family is shown by the fact that Queen Charlotte owned two portraits of Lysons, one by Reynolds and another by Joseph Planta; these are listed in a sale catalogue of 1819 in which Lysons appears amongst the ranks of nobility and celebrated military and political figures of the day (including Nelson, William Pitt and the Duke of Buccleugh) (Christie 1819, no. 30 under English portraits).

${ }^{13}$ Henig 1995, 178-79.

${ }^{14}$ Steer 1966, vi.
} 
Beckford, the Woodchester volume is ranked amongst those 'esteemed some of the most Choice in the Library', alongside Piranesi's Vedute di Roma, Hamilton's vase publications, Montfaucon and Vetusta Monumenta. ${ }^{15}$ Many members of the leading cultural institutions of the day owned a copy of at least one of Lysons' works, such as Henry Englefield. ${ }^{16}$ Sir Joseph Farington's copy is now in the Library of Congress in Washington; Farington was an active and influential member of the Royal Academy and a close friend of Lysons. ${ }^{17}$

The Woodchester and Reliquiae volumes were widely praised for their accuracy and beauty; in 1820 Burke described the works of Lysons as 'remarkable for the industry and accuracy of information with which they have been compiled', and this accuracy has been verified in the course of subsequent excavations. ${ }^{18}$ His volumes include hand-tinted illustrations, some of which were drawn by artists and draughtsmen who were well known in Britain and further afield, including Sir Thomas Lawrence, ${ }^{19}$ Richard and Sir Robert Smirke, Charles and Thomas Stothard ${ }^{20}$ and John Flaxman. $^{21}$

When Lysons was asked, in an examination relating to the Copyright Acts of 1818 , whether the publication of larger collections such as the Reliquiae was of great national importance, he replied 'unquestionably'. ${ }^{22}$ Given the circumstances his response is unsurprising. However, his genuine concern and commitment to the accurate recording, publication and preservation of the sites, and the effort and expense incurred in the process, support his commitment to this cause; ${ }^{23}$ the quality, scale and beauty of the illustrations were seen as essential for attracting aristocratic

\footnotetext{
${ }^{15}$ Phillips 1823. Giovanni Battista Piranesi's Vedute di Roma was a particularly desirable and influential work, shaping the eighteenth-century vision of ancient Rome (Scott 1993, 104). D'Hancarville's publications of Hamilton's vases were also highly sought after; the beautifully produced four volumes of Antiquités etrusques, grècques et romaines... were hugely influential in terms of contemporary taste (see for example, Jenkins and Sloan 1996; Scott 2003, 175; Brylowe 2008). On Fonthill see Richter 2008.

${ }^{16}$ Stanley 1833; Nurse 2004.

${ }^{17}$ Newby 2004.

${ }^{18}$ Burke 1820, 462; Clarke et al 1983; Frere 1982; Wessex Archaeology 2006.

${ }^{19}$ Levey 2004.

${ }^{20}$ Carlyle 2004; Lindley 2012.

${ }^{21}$ Symmons 2004.

${ }^{22}$ Gentleman's Magazine, Vol. 89, Part 1, 460.

${ }^{23}$ Calhoun 2006; see also letter from D. Lysons to T. Cadell regarding losses incurred in the publication of Reliquiae, D. Lysons to T. Cadell, April 14 1823, in Yale University Library, Lysons Family Collection, Series 1; Scott forthoming $2013 \mathrm{~b}$.
} 
subscribers with predominantly cosmopolitan tastes. Todd queries why the Woodchester volume includes text in French; the answer is that it was also aimed at a Continental market, and Continental sales were seen as important. ${ }^{24}$

A concern with the promotion of publications on the Continent can be seen in a letter from John Hawkins to Daniel Lysons, after Samuel's death, in which he discusses the Bignor Guide:

I shall beg leave to reserve for my own use about half a dozen copies one of which I wish to send to the celebrated Mr Böttiger of Dresden, who in the archaeological work he is about to publish, will have the opportunity of saying something upon the subject of the Reliquiae which will promote its sale abroad. I am now in correspondence with him. ${ }^{25}$

The cost of producing the lavishly illustrated volumes and their price were similar to those of other leading publications of the day and they were elaborately and expensively bound. ${ }^{26}$ They were published by Cadell and Davies, one of the most established and renowned firms of publishers and booksellers, who were responsible for producing many of the most impressive publications of the day ${ }^{27}$ for example, they published a number of impressive folio and quarto volumes on archaeology and antiquities, including D'Hancarville's publications of Hamilton's vases. ${ }^{28}$ Because of the huge expense involved in production, publishers were highly selective regarding the volumes they chose to support. Mediterranean classical antiquities, botany, geology and volumes relating to overseas

\footnotetext{
${ }^{24}$ Todd 2004. In the Woodchester volume the text is given first in English then in French and includes a separate title page for the French part: 'Description des antiquités romaines découvertes à Woodchester, dans le comté de Gloucester' (1797). See also Henig 1995, 178 and Hingley 2008, 248. A copy of the volume was intended for Napoleon (Fleming 1934, 22); Reliquiae 1813, Advertisement, iii.

${ }^{25}$ John Hawkins to Daniel Lysons, 18 November 1819, in Steer 1966, 52-3.

${ }^{26}$ See for example Bent 1799 for a list of books and prices; Bohn 1841; 1865. The copy of Reliquiae sold by Christie's in 2009 was bound in contemporary Russia by Ph. Selenka, with his ticket, described by Christie's as 'ornate panelled covers composed of a series of borders in gilt and blind with the central panel enclosed by a wide gilt border with stylized foliate scroll tools and cornerpieces, gilt spine with raised bands, lettered in $2^{\text {nd }}$ and $5^{\text {th }}$ compartments, china blue endpapers, gilt turn-ins, gilt edges' (sale 7725, lot 233). See Scott forthcoming 2013b.

${ }^{27}$ On Cadell and Davies see Besterman 1938. On the House of Strahan and Cadell, and their unrivalled status within the English-speaking world in this period, see Sher 2006, 327-400. On archaeological publishing 18161851 see Scott forthcoming 2013.

${ }^{28}$ Jenkins and Sloan 1996; Scott 2003, 175; Brylowe 2008.
} 
discoveries, in particular, were deemed to be of immense national and international significance and to have a substantial market at home and abroad; for example, in 1797, the year in which the Woodchester was published, Cadell and Davies produced The Natural History of the Rarer Lepidopterous Insects of Georgia, ${ }^{29}$ which comprised two lavish folio volumes with 104 etched and hand-coloured plates and sold for 20 guineas $(£ 21) \cdot{ }^{30}$ Authors were often inspired by the Enlightenment values of humanity and sensibility, which were seen as underpinning civilization, ${ }^{31}$ but books were also used to promote individual and national achievements; ${ }^{32}$ Thornton's The Temple of Flora (1798-1807) was dedicated to Queen Charlotte and contrasted the virtues of peace, asserted through the botanical diversity of the world, with the dangers of (Napoleonic) aggression and conquest. ${ }^{33}$

It is clear that Lysons and his associates, and his renowned publishers, believed that Romano-British remains were of national and international significance, and were prepared to invest heavily in their recording and publication. Lysons' real passion for, and commitment to, the recording and publication of the landscape and antiquities of Britain are evident from his paintings and correspondence, ${ }^{34}$ from the contents of his library, dominated by volumes on British history and topography, and from his own collection of paintings. ${ }^{35}$ In the advertisement to Reliquiae, his aspirations are clear: 'The Editor flatters himself that a work of this description, may be thought an acceptable addition to the libraries of this and other countries'.$^{36}$

\footnotetext{
${ }^{29}$ Smith and Abbot 1797.

${ }^{30}$ Calhoun 2006.

${ }^{31}$ Sher 2006, 33; Haskell 1993.

${ }^{32}$ Sher 2006, 36

${ }^{33}$ Harman 2009, 209-10. Klonk 1996.

${ }^{34}$ Fleming 1934; Steer 1966

${ }^{35}$ Evans 1820; Scott forthcoming 2013.

${ }^{36}$ Lysons 1813, I, Advertisement.
} 
Lysons' predecessors: the national and international significance of Romano-British antiquities

In asserting the national and international significance of Romano-British antiquities Lysons was following in the footsteps of a number of eminent predecessors; Camden's Britannia (1586) was a hugely influential volume, which was first translated from Latin into English in 1610 and received considerable recognition in Britain and further afield. ${ }^{37}$ Although it covered Britain's past from the earliest times to the Norman period, the main focus is the Roman period. Camden's work transformed topographical and historical study through fieldwork and through the scrutiny of a wide range of evidence, including original documents, linguistic evidence and artefacts, which were seen as important sources of information about past societies. ${ }^{38}$ His aim was 'to restore Britain to its Antiquities and Antiquities to Britain', ${ }^{39}$ although he focused primarily on England and Wales; as shown by Richardson, his writing made a 'decisive contribution to the "discovery of England" and to the emergence of a real sense of "Englishness" through the study of local historical foundations and achievements'.$^{40}$ A new translation (1695), edited by Edmund Gibson, was important for stimulating further interest in Roman Britain; a second edition appeared in 1722 and further revisions by Richard Gough were published in 1789 and $1806,{ }^{41}$ testifying to the enduring appeal of the volume; the 1806 edition filled four impressive folio volumes. ${ }^{42}$

John Horsley's Britannia Romana (1733) was also influential to the end of the eighteenth century and beyond. ${ }^{43}$ Horsley similarly believed in the national significance of Romano-British remains, and in the dedication to Sir Richard Ellys, he stresses the contemporary relevance of his project:

\footnotetext{
${ }^{37}$ Herendeen 2004; Richardson 2004, 113.

${ }^{38}$ Camden 1586, translated by Edmund Gibson 1695; Herendeen 2004.

39 Preface, Camden 1586, translated by Edmund Gibson 1695.

40 Richardson 2004, 115.

${ }^{41}$ Ayres 1997, 102-4; Sweet 2001, 185; Sweet 2004, 160.

42 Richardson 2004, 113.

${ }^{43}$ Ayres 1997, 103; Sweet 2004, 162; Hingley 2008, 155.
} 
In the following account of the remains of Roman grandeur in our island, you will find some traces of that elegance of life, which you, sir, so happily enjoy. That you may long continue to shine in it; that God may long preserve you to do farther important services to religion, and to your country; and that in a degenerate and corrupt age you may long adorn, and protect the cause and interests of piety, liberty and virtue. ${ }^{44}$

Horsley believed that it was essential to present all kinds of evidence, for example the sizes and shapes of stones and the scale of letters and figures, and criticized earlier works, such as Camden's Britannia, for their inaccuracy. ${ }^{45}$ Horsley's work did not provide a coherent history of Roman Britain, but was an essential addition to the libraries of specialists and non-specialists alike, and formed a much-admired foundation for future scholarship. ${ }^{46}$

Lysons' interest in topography, his belief in the national and international significance of Romano-British remains, and his appreciation of the importance of all forms of evidence as a source of information about life in the past, were certainly influenced by the work of Camden and Horsley. They can be seen, for example, in his concern to record all forms of evidence, including many small finds, such as fragments of pottery and wall plaster; Lysons refers to both Camden and Horsley throughout his work and possessed copies of both volumes. His volumes are particularly admired, however, for their depictions of Romano-British art, most notably mosaics and sculpture. ${ }^{47}$ While both Camden and Horsley discuss examples of Romano-British art, and Horsley devotes considerable attention to sculpture, their approach is descriptive rather than explanatory and there is little concern with aesthetic considerations. ${ }^{48}$

\footnotetext{
${ }^{44}$ Horsley 1733, Preface.

${ }^{45}$ Horsley 1733; Levine 1991, 393; Hingley 2008, 155-6.

46 Levine 1991, 402; Ayres 1997, 104; Hingley 2008, 155. Samuel Lysons possessed a copy of Horsley's volume in his personal library (no. 855 in Evans 1820).

${ }^{47}$ Morgan 1886, xxii; Haverfield 1924, 80-1; Henig 1995, 178; Johns 2001; Todd 1996, 100.

${ }^{48}$ See for e.g. Horsley 1733, 327; Henig 1995, 178.
} 
'Amidst the wilds of barbarism, a civilised nation': the discovery, collection and recording of Romano-British art

Lysons' efforts and achievements in the recording and publication of Romano-British art, mosaics in particular, set him apart from his predecessors, and are particularly impressive, and perhaps surprising, given the often negative perceptions of Romano-British art in this period. Britain was largely seen as a military outpost of the Roman empire, and considerable attention was devoted to the recording of military sites and antiquities; the most impressive example is perhaps William Roy's major monograph The Military Antiquities of the Romans in Great Britain $(1793) .{ }^{49}$ As a result of this preoccupation with military aspects, the art and architecture of the province were often viewed unfavourably: for example, Essex questions Agricola's description of temples and other fine structures in Britain:

If we accept a few altars, \&c. which are so wretchedly executed, that they would a this time disgrace the hand of a common mason ... it may indeed be doubted, whether those arts ever arrived to any degree of perfection in Britain while the Romans were masters of it. $^{50}$

However, throughout the course of the eighteenth century the discovery of increasing numbers of artefacts of non-military origin began to show that Roman Britain had been an established and civilised part of the Roman empire. ${ }^{51}$ The most impressive of these artefacts were seen as worthy of serious attention on the part of collectors and connoisseurs; ${ }^{52}$ for example, Humfrey Wanley, the librarian of Robert Harley, the earl of Oxford, attempted to acquire a number

\footnotetext{
${ }^{49}$ In the early part of the eighteenth century Roman houses that came to light were often interpreted as the residences of military commanders (Yonge 1788, 193; Hingley 2008, 236). See Hingley 2008, 139-48 on William Roy.

${ }^{50}$ Essex 1774, 87-8.

51 Pownall 1795, 2; Sweet 2004, 182; see also Hingley 2008, 157-237, 243. By the latter part of the century it was possible to identify a number of buildings with mosaics as examples of houses built by Roman settlers or by important native figures. For a detailed overview see Hingley 2008, 169-208 and Nurse 2007.

52 For aristocratic interests in Roman Britain, see Ayres 1997, 84-114; Henig 1995, 176-85.
} 
of Roman altars from the collection of the antiquary John Warburton for the new library at Wimpole Hall, Cambridgeshire. ${ }^{53}$ Mosaics also attracted significant attention: for example, the 4 th earl of Cardigan transported a section of a mosaic discovered at Cotterstock (Northants) in about 1737 to his house at Deene Park, where it was inserted into the floor of a summerhouse. ${ }^{54} \mathrm{~A}$ tapestry of the Littlecote pavement (Wilts) -the pavement had been discovered in the grounds of Littlecote House in 1727- hung in Littlecote House until $1985 .{ }^{55}$ The Stonesfield mosaic (Oxon.) was recreated in textile form in a 'nine-foot carpet with all the colors (sic) of the original', ${ }^{56}$ and has been shown to have exerted a considerable influence on contemporary tastes. ${ }^{57}$

Some of the more dramatic finds that came to light in the latter part of the eighteenth century were acquired for important collections. For example, an inlaid bronze statuette portraying a cuirassed emperor, possibly Nero, from Coddenham (Suffolk) was in the collection of the earl of Ashburnham of Barking Hall (Suffolk). ${ }^{58} \mathrm{~A}$ drawing of it was engraved in 1807 by James Basire and appeared in Vetusta Monumenta. ${ }^{59}$ Another impressive discovery was the bronze helmet found at Ribchester in Lancashire as part of a hoard, which was acquired by Sir Charles Townley; the helmet was discussed at the Society of Antiquaries in 1798 and its beauty and significance are celebrated in a letter published in Archaeologia: ${ }^{60}$

I beg leave to request the attention of the Society whilst I hazard a conjecture upon the nature of the personage to be represented on the beautiful and singularly curious relic of antient art, exhibited by Mr. Townly from his rich and unparalleled collection of Greek and Roman antiquities. ${ }^{61}$

\footnotetext{
${ }^{53}$ Hutchinson 1776-8, I, 60; Sweet 2004, 163.

${ }^{54}$ Gale 1737; Upex 2001, 62-3; Hingley 2008, 172.

${ }^{55}$ Colt Hoare 1822, 118-20; Henig 1995, 178.

${ }^{56}$ Brome to Rawlins, 22 December 1735, Bodl. MS. Ballard 19, fols. 61-62; Levine 1978, 355.

${ }^{57}$ Freshwater, Draper, Henig and Hinds 2000.

${ }^{58}$ Henig 1995, 181.

${ }^{59}$ Vetusta Monumenta IV, 1815, pl. xiii.

${ }^{60}$ Weston 1800, 223-226.

${ }^{61}$ Weston 1800, 223.
} 
The helmet was beautifully drawn, probably by Thomas Underwood (1772-1835), who was commissioned by Townley in 1798, although it was Basire's drawings which were engraved and published. ${ }^{62}$ These objects were desirable because of their classical form and beauty, and their publication in the prestigious Vetusta Monumenta, and the recognition of eminent collectors and connoisseurs, undoubtedly enhanced the status of Romano-British art.

The restrictions on Continental travel served to focus further attention on British classical sites and antiquities in this period. Numerous discoveries and rediscoveries of villas and mosaics from the 1780s onwards, some of which were extremely impressive in scale, provided an excellent opportunity to further assert Britain's place at the heart of a shared classical heritage. In particular, they were used to challenge the notions that Britain had been a military outpost and cultural backwater in the Roman period and that its climate and national character were incompatible with artistic achievement. ${ }^{63}$

\section{'Wild poets, coarse versifiers, and frigid colorists': International rivalry in the arts and sciences}

Lysons was at the heart of an intellectual elite which genuinely believed that the encouragement and promotion of British intellectual and artistic achievement was an essential undertaking in the national interest. ${ }^{64}$ In 1797 he was elected Fellow of the Royal Society, going on to become vice-president and treasurer in 1810. In 1798 he was elected director of the Society of Antiquaries, a post to which he was re-elected annually until he resigned in 1809; he became its vice-

\footnotetext{
${ }^{62}$ Vetusta Monumenta, IV, 1815, pl. ii; Lewis 2007, 114, figures 77 and 78; Henig 1995, 181, figure 107.

${ }^{63}$ For example, in 1793, while working on a portfolio of Gloucestershire views, Lysons came to hear of the rediscovery of a mosaic pavement at Woodchester. The excavation of a vault 'for the interment of the late John Wade Esq. of Pud Hill' allowed him to ascertain the dimensions (48 ft. $10 \mathrm{in}$.) of an 'Atrium', and with the support of Banks he exploited the opportunity fully. Excavations began in 1793, took place again in the spring, autumn and winter of 1794, again in the autumn of 1795 through to the summer of 1796. Lysons 1797, plate vi; St Clair Baddeley 1926; Fleming 1934, 20; Hingley 2008, 247-50. Scott forthcoming 2013a.

${ }^{64}$ Gascoigne 2004.
} 
president in 1812. He was an active member of the Royal Academy, and in 1818 was requested to accept the position of antiquary professor at the Academy with the support of the Prince Regent. ${ }^{65}$ Sir Joseph Banks, a close friend and supporter of Lysons, was perhaps the most influential figure within these intellectual circles. As president of the Royal Society Banks was instrumental in institutionalising science within foreign policy and imperial administration, asserting Britain's place at the forefront of scientific endeavour and exploration. ${ }^{66}$ The perceived national significance of this is encapsulated perfectly by Cook and King in 1785 :

Let us not therefore think so meanly of the times in which we live, as to suppose it possible that full justice will not be done to the noble plan of discovery, so steadily and so successfully carried on, since the accession of his Majesty; which cannot fail to be considered, in every succeeding age, as a splendid period in the history of our country, and to add to our national glory, by distinguishing Great Britain as taking the lead in the most arduous undertakings for the common benefit of the human race. ${ }^{67}$

The Royal Society, the Society of Antiquaries of London and the Royal Academy were all housed in Somerset House, one of the most impressive public buildings constructed in London in the latter part of the eighteenth century, in a dramatic assertion of British intellectual and cultural leadership. ${ }^{68}$ As shown by Hoock, national institutions for the arts flourished in this period; the Royal Academy's annual entertainments were extravagant and highly symbolic, honouring the achievements of the Academy and the English School. ${ }^{69}$

\footnotetext{
${ }^{65}$ Graves 1906, V, 121; Scott forthcoming 2013a.

${ }^{66}$ Gascoigne 1998; Hoock 2010, 16. On eighteenth-century patriotism and the development of national consciousness, see for example, Newman 1997; Colley 1992, 1986, 1984; Kidd 1996. On science and national identity, see for example, Gascoigne 1998. On patriotism and rivalry in the arts, see for example, Craske 1997, Newman 1997, 111-13 and Hoock 2010a and b.

${ }^{67}$ Cook and King 1785, Ix. See also Gascoigne 1998; Mackay 1985.

${ }^{68}$ Hoock 2003a, 37.

${ }^{69}$ Hoock 2003a, 52-79; 2003b, 41. At the Royal Academy's Annual Entertainment in April 1798 the list of those attending included 3 members of the royal family, 11 earls, 4 viscounts, 5 bishops, Sir Joseph Banks, Richard
} 
Lysons was also involved with other institutions established to support and promote the arts. For example, he is listed as a subscriber to the British Institution for Promoting the Fine Arts in the United Kingdom. ${ }^{70}$ The patron of this organisation was the King, its vice-patron the prince of Wales, its president the earl of Dartmouth. Subscribers included dukes, bishops and other members of the clergy, and among those listed are Richard Payne Knight and Sir Richard Colt Hoare. ${ }^{71}$ Lysons had paid a subscription of $£ 52$ and 10 shillings, which will have entitled him to life governorship. The Institution established a gallery where the works of British artists could be displayed and collectors could conspicuously demonstrate their wealth, taste and patriotism without actually needing to acquire any British art. ${ }^{72}$ While many members of the Institution showed little genuine concern for British art, the cost of subscription was a considerable financial investment on Lysons' part and suggests a genuine commitment to its cause. ${ }^{73}$

The intention behind investment in national institutions for the arts was to counter European claims that Britain lacked the necessary climate and national character for an artistic renaissance. ${ }^{74}$ The notion that a link existed between climate, national character and artistic achievement had long been asserted: Montesquieu described England as 'a nation so distempered by the climate as to have a disrelish of everything, nay even of life', ${ }^{75}$ while the French scholar Jean Baptiste Dubos (1670-1742), in his influential and widely disseminated Critical Reflections on Poetry and Painting, argued that Britain's climate was incompatible with artistic excellence:

\footnotetext{
Payne Knight, Charles Townley, Charles Greville (nephew of Sir William Hamilton) and Samuel Lysons (Oracle and Public Advertiser, London. Monday April 23, 1798. Issue 19916).

${ }^{70}$ Colley 1992, 178; Hoock 2003, 53.

${ }^{71}$ Morning Chronicle, Monday 9 June 1806, Issue 11563.

${ }^{72}$ Colley 1992, 179; Hoock 2003b, 46.

${ }^{73}$ On development of interests in British art alongside persistence of cosmopolitanism and the collecting of Old Masters, see Hoock 2003a 107-23; 2003b, 46; 2010b. See also Newman 1997, 21-48, particularly 45-7 on contradictions: 'On tour, an Englishman might display his personal superiority before both Continentals and other Englishmen by despising the best and costliest that Europe could produce; at home, nothing English could compare with what he had seen abroad' $(1997,45)$.

${ }^{74}$ Hoock 2003a, 5.

${ }^{75}$ Montesquieu 1751, XIV, chapter 13.
} 
It would be needless to use many arguments to prove, that there are countries, which have never produced any eminent painters or poets. Everybody knows, for instance, that we have never had from the extremities of the North but wild poets, coarse versifiers, and frigid colorists (sic). Painting and poetry have never approached the pole nearer than the latitude of Holland; and even in this province we have seen only a poor starved kind of painting ... The difference of climates which shews itself sensibly in the plants, must extend itself likewise to the brain. ${ }^{76}$

Similar views were proposed by Le Blanc. ${ }^{77}$ The link between climate, national character and artistic achievement was lent further authority through the works of Winckelmann, who argued that national characteristics were shaped by 'heaven', which was seen as causative and constant: for example, the Greek sun resulted in greater exposure of the human body and hence allowed Greek artists to appreciate and reproduce its form better. ${ }^{78}$ As noted by DaCosta Kaufmann, Winckelmann's status, the reception of his Geschichte der Kunst des Altertums, and the fact that he expressed these views at a key point in his book all served to enhance their authority. ${ }^{79}$

The notion that Britain's achievements were limited by climate and national characteristics were countered by claims that the deficiencies were due instead to a lack of institutional support for native arts and could therefore be overcome:

The obstructions that have hitherto lain in the way of our acquiring art, were not naturally connected with our climate, but arose from mere accident, the fluctuation of opinions, and

\footnotetext{
${ }^{76}$ Dubos, 1748 Vol. II, 110-11, transl. Nugent.

77 Le Blanc 1747. Such views were widely held; see e.g. the work of the Swedish architect and writer Karl August Ehrensvärd (1745-1800) (DaCosta Kaufmann 2004, 37).

${ }^{78}$ Winckelmann 1765; DaCosta Kaufmann 2004, 37.

${ }^{79}$ Winckelmann 1764; 1765.
} 
of those things that depend upon opinions, and consequently, that although these difficulties might lie before us at one time, they might possibly be removed at another. ${ }^{80}$

The perceived national importance of British cultural achievement is clear from a speech given by the Prince Regent at the Royal Academy dinner in 1811, as described by Farington:

When He saw so much which manifested the great improvement in Art He felt proud as an Englishman that He might with confidence expect that as this country had risen superior to all others in Arms, in military and naval prowess, so would it in Arts. ${ }^{81}$

William Hayley similarly championed British artistic endeavour in the face of foreign competition in his Essay on Sculpture, which celebrates the achievements of the eminent neoclassical draughtsman and sculptor John Flaxman (1755-1826)(see below for Flaxman's contribution to the Woodchester volume):

So may the modern lord of Sculpture's sphere,

Whose mighty hand to many an art was dear---

May lofty Angelo thy mind inflame,

As happily to vie with Tuscan fame!

Then shall thy country, while thy works display

Force, feeling, truth and beauty's moral sway,

Radiant at last, with sculptural renown,

(a gem long wanting in her lucid crown,)

Feel new distinction animate her heart,

${ }^{80}$ Barry 1809, 180; Hoock 2003, 5.

${ }^{81}$ Farington Diary, XI, 3919, 27 April 1811. 
And high precedence hold in every art. ${ }^{82}$

Flaxman proposed the erection of an imposing monument to Britannia near Greenwich Observatory, which would assert Britain's place at the heart of a new empire:

It is also to be remembered that the port of the Metropolis is the great port of the whole kingdom; that the Kent Road is the ingress from London to Europe, Asia and Africa; and that, as Greenwich hill is the place from whence the longitude is taken, the monument would, like the first milestone of Rome, be the point from which the world would be measured. ${ }^{83}$

However, there was not a straightforward shift from cosmopolitanism to nationalism; the Royal Academy's support for native arts took the form of a 'cosmopolitan patriotism' which celebrated and promoted British artistic achievements in terms of its conformity to shared European ideals and values. ${ }^{84}$ Those who attended events at the Academy included aristocrats with predominantly cosmopolitan tastes, but also members of the intellectual elite, of which Lysons was a member, who were genuinely committed to supporting British art and artists and promoting their achievements in Britain and further afield. ${ }^{85}$

As one among an intellectual elite who were instrumental in establishing and promoting national artistic and intellectual achievements in a period characterised by intense cultural rivalry, Lysons was genuinely concerned to record Romano-British remains accurately and present them to the widest possible audience. In particular, he was keen to generate funds for their preservation and

\footnotetext{
${ }^{82}$ Hayley 1800, Epistle 1, 10-11, lines 138-47.

${ }^{83} \mathrm{~A}$ Letter to the Committee for raising the Naval Pillar or Monument under the patronage of his Highness the Duke of Clarence, Dec. 1799. Reprinted in J. Physick 1969, Designs for British Sculpture 1680-1860, 169; Craske $1997,258-9$.

${ }^{84}$ Hoock 2003a, 109.

${ }^{85}$ Hoock 2003b, 46.
} 
publication, which he believed to be in the national interest. ${ }^{86}$ While he benefited in many ways from his aristocratic connections, ${ }^{87}$ this did not extend to financial support for the preservation and presentation of the sites; Lysons therefore needed to convince this audience that investment was worthwhile. In order to do so it was essential to overcome three aesthetic prejudices: that Roman art was inferior to Greek, ${ }^{88}$ that British antiquities were inferior to their Continental equivalents, and that illustrations of them were rather dull as a result of an overriding concern with visual accuracy. ${ }^{89}$ Lysons was also at the heart of an intellectual elite who were constantly striving to assert Britain's cultural leadership in Europe, with a view to challenging the widely held notion that Britain's climate and national character were incompatible with artistic excellence. The ways in which he asserted the importance of Romano-British sites and antiquities, and of British achievements in excavating, recording and preserving them, while also demonstrating the suitability of the British landscape and climate for the cultivation of artistic excellence, both in the past and present, will now be explored through an evaluation of his publications.

\section{'With Grecian Sculpture's perfect sons to vie': Samuel Lysons and the art of Roman Britain}

A key concern throughout the works of Lysons is to establish the merit and significance of British discoveries in relation to Roman remains found elsewhere. The title page of the first volume of

\footnotetext{
${ }^{86}$ While the royal family visited his excavations, funding for the preservation of the sites was not forthcoming: 'I almost despair of any assistance from the Prince Regent towards the permanent conservation and exhibition of our Roman Villa' (John Hawkins to Samuel Lysons, 26 June 1812, in Steer 1966, 14). Lysons produced engravings of the mosaics at Bignor with the intention of raising money through their sale to finance the construction of buildings over the remains. See for example, John Hawkins to Samuel Lysons, 2 November 1813, in Steer 1966, 13. For the wider context, see Hoock (2007) on the British state and archaeology; Scott forthcoming 2013a.

${ }^{87}$ Through the influence of Banks, Lysons became acquainted with the royal family and established a close relationship with Princess Elizabeth. In 1804 he was appointed Keeper of the Tower Records, in part due to his royal connections, and became responsible for royal letters, state papers and parliamentary documents. Lysons made a very significant impact on the organization and publication of the records, and the position came with a salary of $£ 290$ a year increased to $£ 500$ in 1809 (Bayley 1821, II, 259; Fleming 1934, 28).

${ }^{88}$ Winckelmann 1765; 1767. Payne Knight 1809.

${ }^{89}$ Smiles 2007, 124.
} 
Reliquiae includes two roundels with depictions of Roma and Britannia taken from coins, and it is clear that they should be seen as equal in status. ${ }^{90}$ The national significance of Roman remains in Britain is illustrated through the dedications to George III in Woodchester and Reliquiae (FIGURE 1), and is made clear through descriptions and watercolours of the large-scale excavations: for example, in a sketch of the excavations at Frampton, Lysons (if it is he) directs a substantial military workforce while a woman and child make their way across the field to view the excavation (FIGURE 2).

In comparing the British remains to those on the Continent Lysons situates them firmly within a pan-European classical context, making excellent use of his extensive knowledge of classical sources and his familiarity with a wide range of sites and material in Britain and Europe. ${ }^{91}$ This is evident in his discussion of the mosaic pavement, for example in the advertisement for Reliquiae:

These pavements are said by Pliny ${ }^{92}$ to have been introduced among the Romans from Greece at the time of Sylla: they were at first only employed in their temples, but from the discoveries at Pompeii, it appears that before the time of the Emperor Titus they were frequently used in private houses. In the reign of Hadrian they appear to have been in very general use, not only in Italy, but in the provinces of the Roman empire. Many have been discovered in France, Spain and Switzerland. But perhaps no country has afforded a greater number and variety than England, or of larger dimensions. The pavements formerly found at Littlecote in Wiltshire, and Stunsfield in Oxfordshire, and those discovered of late years at Horkstow in Lincolnshire, and near Frampton in Dorsetshire, may vie in point of size with those of the greatest celebrity on the Continent; whilst that of the Cavaedium tetrastylon, in the remains of the Roman villa at Woodchester, is perhaps the largest ever discovered,

\footnotetext{
${ }^{90}$ Lysons Reliquiae 1813, I; Henig 1995, 180.

${ }^{91}$ For description of discoveries at Pompeii: Account of the Discoveries at Pompeii, communicated by Sir William Hamilton. Read at the Society of Antiquaries, 26 January and 2-9 February, 1775. Archaeologia 1776, 4, 160-75. See Evans 1820 for the contents of Lysons' library. Lysons makes extensive use of Vitruvius and possessed a rare edition, nos 1785 and 1786 in Evans 1820. See for example the discussion of tesserae: footnotes 11 and 12, in Woodchester 1797, 4.

92 Pliny, Natural History 36, 64/189.
} 
except the pavement from Otricoli near Rome, now laid down in an apartment of the Vatican. ${ }^{93}$

Lysons asserts the quantity, quality and scale of the British remains -in particular the 'Great Pavement' from Woodchester-which was also beautifully recorded in a series of plates (FIGURE $3) ;{ }^{94}$ he exhibited an engraving of this mosaic at the Royal Academy, at a time when visitor numbers were often in excess of 50,000 and the audience included ambassadors from many nations. ${ }^{95}$ While accuracy was a particular concern of Lysons and his associates, ${ }^{96}$ they were also talented artists, draughtsmen and engravers. Lawrence contributed drawings for two of the engravings for Woodchester, and Richard Smirke may have assisted with the drawing of the 'Great Pavement'. ${ }^{97}$ Richard Smirke also assisted with the recording of mosaics at Withington and Bignor. ${ }^{98}$

The quantity, scale and beauty of the plates is exceptional in the context of contemporary Romano-British scholarship, and equalled that of better-known publications on Greek and Roman antiquities. It is notable that Lysons and his associates did not generally 'repair' flaws, as was often the case with the recording of classical antiquities in this period (for example as d'Hancarville did with Hamilton's vases) and took great care to record smaller finds. ${ }^{99}$ Where reconstruction was attempted, the state of the original was clearly shown. ${ }^{100}$ Lysons' careful integration of text and

\footnotetext{
${ }^{93}$ Lysons 1820, 8-9. For comparative material in Lysons' library, see for example Ornati delle pareti ed i pavimenti dell'antica Pompeii, Naples 1796. No. 1333; Pownall's Antiquities of the Provincia Romana of Gaul, 1788, no. 1459; Schmidt, Antiquités de la Suisse, 1771; no. 1519 in Evans 1820.

${ }^{94}$ Lysons 1797; for additional plates, Reliquiae 1813 , I, iii, plates X-XL.

${ }^{95}$ Graves 1906, 121; Fleming 1934, 4.

${ }^{96}$ For discussion of the growing concern with accuracy, see e.g. Lindley 2012; Nurse and Mordaunt Crook 2011; Smiles 2007; Smith 2002. William Fowler, a master builder from Lincolnshire, also came to be well known for his drawings of mosaics, although he did not possess the archaeological skills of Lysons (Fowler 1801-7; McConnell 2004; Sweet 2004, 184). A great rivalry developed between Lysons and Fowler, whose volume included twenty sets of engravings-most of Roman mosaics-including some copies of earlier drawings and engravings and a new version of the Stonesfield pavement. For rivalry, see Samuel Lysons to Joseph Banks (26 October 1797 in Fleming 1934, 26). See also Sweet 2004, 184.

${ }^{96}$ Letter from John Hawkins to Samuel Lysons (29 May 1814), Steer 1966, 18.

${ }^{97}$ St Claire Baddeley 1926, 94; Fleming 1934, 22. For further discussion see Henig 1995, 180; Todd 1996, 95; Hingley 2008: esp. 248.

${ }^{98}$ Reliquiae 1817, II, i, plates XIX and XX. See also Cosh and Neal 2010, 203, pl. 213; for further contributions by Richard and Robert Smirke, see Reliquiae 1817, II, i, plates III, IV, VI, VII, XV, XVI, XVII.

${ }_{99}$ d'Hancarville 1766-7; Brylowe 2008, 54.

${ }^{100}$ Woodchester 1797, plates XXXVIII and XXXIX.
} 
image, and his recording of small finds, stand in stark contrast to many contemporary publications on Continental classical antiquities. Winckelmann's Monumenti antichi inediti, for example, was known for the poor quality of its images; Ballantyne argues that Payne Knight's Specimens of Antient Sculpture, which included high-quality images with a detailed commentary, was inspired in part by the poor quality of the illustrations in Winckelmann's account. ${ }^{101}$ The illustrations in Payne Knight's work draw attention to the material qualities of the sculptures, unlike Winckelmann's, which are largely outlines. ${ }^{102}$ Although Woodchester was published a number of years before Specimens, Lysons' illustrations similarly emphasize the material qualities of the objects, and particular attention was paid to the hand-tinting of the engravings. ${ }^{103}$

In his discussion of the mosaics, sculptures and other finds, Lysons makes detailed comparisons between British and Continental discoveries through reference to examples discussed in contemporary European publications and in well-known sources such as Montfaucon, de Caylus and Winckelmann. ${ }^{104} \mathrm{He}$ emphasises similarities in style and materials; ${ }^{105}$ for example, in describing a pavement from Bignor, he notes that

the smaller one contains a representation of the rape of Ganymede, apparently as well executed as the nature of the materials would admit; the large one is subdivided into six

\footnotetext{
${ }^{101}$ Arnold and Bending 2002, 423; Ballantyne 2002.

${ }^{102}$ Winckelmann 1767. See for e.g. plates 40 and 54. Payne Knight 1809. See for e.g. Apollo, plate XLIII, vol. I of Specimens of Antient Sculpture. For a detailed discussion of the illustrations see Ballantyne 2002.

${ }^{103}$ While Lysons' interests were focused on Britain, he socialized regularly with well-known collectors and connoisseurs of classical art, such as Charles Townley and Richard Payne Knight, and took an interest in their affairs. For example, the activities and opinions of Payne Knight are discussed by John Hawkins in letters to Lysons, most notably in relation to Payne Knight's views on the Elgin Marbles (John Hawkins to Samuel Lysons, 2 July 1815 in Steer 1966, 26; Hawkins to Lysons, 3 Aug. 1816, in Steer 1966, 32).

${ }^{104}$ Haskell 1993, 131-44 on Montfaucon and Caylus. Lysons possessed copies of de Caylus 1752, no. 400, Montfaucon 1722, no. 1311 and Winckelmann 1767, no. 1814 in Evans 1820. For additional sources concerning classical sites and antiquities, see for example nos. 1333, 1554, 1556, 1558 in Evans 1820. ${ }^{105}$ Lysons exploited the talent of the eminent chemist Humphry Davy, a fellow member of the Royal Society (Knight 2004). He carried out a scientific examination of the colours of wall paintings at Bignor (Reliquiae 1817, III, 3, note B; Davy 1817; Rees-Jones 1990, 93-101). The vibrancy of the colours used at Bignor, and the similarities noted between these pigments and those used in the baths of Titus in Rome and in the houses of Pompeii and Herculaneum, allowed Lysons to situate the British remains within a European classical context, clearly demonstrating that this part of Britain had reached a comparable degree of civilisation.
} 
irregular hexagonal compartments, within which are figures of dancing nymphs much in the style of those which appear in the Roman paintings discovered in Italy. ${ }^{106}$

Through reference to Swiss discoveries, Lysons suggests that the same mosaicist, or artist, may have been at work in both Britain and Switzerland (FIGURE 4): ${ }^{107}$

In the year 1708, a mosaic pavement was discovered at Avenches in Switzerland, the Aventicum Helvetiorus of Antonine's Itinerary, called by Tacitus Gentis Caput, which was patronized in a particular manner by the emperors Vespasian and Titus. Of this pavement a particular account was published by Mr. De Schmidt, Seigneur de Rossan, in his Recueil d'Antiquités de la Suisse, from which it appears so exactly to resemble the large pavement first discovered at Bignor that there seems good ground for conjecturing that they are the work of the same artist. ${ }^{108}$

Schmidt's Recueil d'Antiquités de la Suisse includes detailed descriptions and explanations of the finds and a number of well-drawn plans and illustrations, including small finds such as fragments of wall plaster and lamps, for which Schmidt employed 'Mr Zingg, très célèbre Artiste Suisse' ${ }^{109}$ The similarities between the mosaics at Avenche and Bignor are somewhat overstated, but the comparison serves to emphasise Britain's place within a pan-European classical tradition while also, through the inclusion of plates of both the British and the Swiss examples, demonstrating that British skills in recording these equalled or surpassed those of well-known Continental antiquaries and artists.

On the other hand, Lysons also had to account for a number of apparent shortcomings in the remains. For example, he uses his knowledge of discoveries in Europe and his grounding in the

\footnotetext{
${ }^{106}$ Lysons 1820, 10.

${ }^{107}$ Schmidt 1771, no. 1519 in Evans 1820.

108 Lysons 1820, 35.

${ }^{109}$ Schmidt von Rossan 1771, preface; Evans 1820, no. 1519.
} 
Classics to account for irregularities in the plan of the villa at Bignor; the British villa is not inferior because of these, as similar irregularities can be seen elsewhere, even close to Rome:

In most of the remains of the Roman villas are similar deviations from regularity; and the same occur in the remains of a Roman villa discovered at Rielves in Spain, published in 1788 by Don Pedro Arnal. We need not be surprised that such instances should occur in so remote a province of the Roman empire as Britain, when Cicero, giving his brother Quintus an account of the progress of his villa near Rome, complains that the architect had neither placed the columns upright, nor in a straight line. ${ }^{110}$

Where the execution of mosaics is deemed to be inferior to that of Continental examples, this is not attributed to a lack of skill on the part of the artist but to the materials used. It does not, therefore, detract from their significance:

There are, nevertheless, few of the figures, that occur in these works, so marred by a stubborn process, as not to preserve evident traces of the graceful originals whence they were derived; and many forms and attitudes, long known and admired in gems, in paintings, and basso-relievos, may be easily recognised in the pavements of these British-Romano (sic) edifices. ${ }^{111}$

Examples of sculpture discovered at Woodchester are compared with some of the finest examples in Europe. The remains of feet from Woodchester suggest a figure in an attitude similar to that of a Meleager in the Vatican Collection; a fragment of a group of Cupid and Psyche (Plate XXXVII) has nearly the same attitude 'though not so good as that of the group in the Grand Duke's Collection, engraved in the Museum Florentinum' (FIGURE 5). ${ }^{112}$ The Diana and bull sculpture is

\footnotetext{
${ }^{110}$ Lysons 1820, 14.

${ }^{111}$ Reliquiae $1813, \mathrm{I}, \mathrm{i}$, advertisement.

112 Lysons 1797, 10-11. In his evaluation of the quality and date of the sculptures Lysons was influenced by the work of Winckelmann. There is a broad sense throughout the publications that the highest-quality and most impressive sculptures and mosaics are of an earlier period. Lysons' conclusions, while often inaccurate by
} 
deemed to be less impressive in execution, 'the folds of the drapery being too strongly marked', but these perceived shortcomings are not evident in the beautifully executed engravings (FIGURE 6). ${ }^{113}$ Lysons employed the services of John Flaxman (1755-1826) who 'by following the lines of the drapery with clay, ascertained in the most satisfactory manner what the defective parts of the figure must have been' ${ }^{114}$ This reconstruction is illustrated alongside the original in plate XXXVIII. Flaxman was well known in Europe, and Hayley's belief in his potential for enhancing the status of art in Britain is perhaps equally relevant in the context of Romano-British art:

My daring verse avows the patriot aim

To quicken Britain's love for boundless fame;

To raise her pitch of emulation high,

With Grecian Sculpture's perfect sons to vie.

When foreign pride would British minds enchain,

Perish the doubt, preposterously vain,

That mental tyrants arrogantly start

To limit England in the sphere of art! ${ }^{115}$

'No... finer verdure': Lysons' landscapes

A key element within the assertion of British cultural and artistic achievements in this period was the growing support for a national school of painting. ${ }^{116}$ Of particular relevance here is landscape painting, which had emerged as an important genre in the second half of the eighteenth

modern criteria, are also unsurprising given the widely accepted view that the quality of art degenerated dramatically in the later empire as a result of moral decline and decadence. This notion underpins the work of Caylus and Gibbon (Gibbon 1826; Haskell 1993, 187). On Winckelmann, see for example Marchand 1996, 7-16; Scott 2006. Lysons' copy: Winckelmann 1767, no. 1814 in Evans 1820.

${ }^{113}$ Lysons 1797, 10, plates XXXVIII and XXXIX.

${ }^{114}$ Lysons 1797, 10, footnote 24; Plate XXXVIII, figure 2.

${ }^{115}$ Hayley 1800, Epistle 2, 34, lines 159-66.

${ }^{116}$ See for e.g. Hoock 2003a. 
century, fuelled by the demands of a prosperous landed gentry, and which represented a growing sense of pride in regional and national identity while also emphasising links with a 'classical golden age ${ }^{\prime}{ }^{117}$ This interest in landscape painting was inspired by the work of Continental masters, most notably Salvator Rosa's dramatic depictions of wilderness, which came to be described as 'sublime', and Claude Le Lorrain's 'beautiful' landscapes. In the latter part of the century 'picturesque' scenes proved particularly appealing; a vogue for picturesque tours of Britain developed in part as a result of the restrictions placed on travel to the Continent. It was believed that such scenes should include variety and intricacy, and as such they were often characterized by contrasts of lighting. ${ }^{118}$ The topographical tradition, which was concerned with the depiction or description of a particular locality, was also important: Joseph Farington, a close friend of Lysons, worked within this tradition, and the growing interest in geology contributed to the development of this approach, particularly in the first part of the nineteenth century. ${ }^{119}$ By the second half of the eighteenth century British engravers and watercolourists started to attract international recognition: Sir Thomas Lawrence, also a close friend of Lysons, reported with pleasure that his tour of the Continent, painting leading military and political figures for the Prince Regent, had raised the 'Character of England'. ${ }^{120}$

Lysons was passionate about etching, and regularly practised with Lawrence; the results of his endeavour can be seen in many of his publications, such as Views and Antiquities in the County of Gloucester (1791-4) and later in volumes of Magna Britannia (1808-22) and Woodchester (1797); around 300 watercolours of his are now in the British Library. ${ }^{121}$ Whilst in London, he attended the lectures of Sir Joshua Reynolds, a leading advocate of British art, ${ }^{122}$ and from 1785 he regularly

\footnotetext{
${ }^{117}$ Klonk 1996, 9; Craske 1997, 114; Harman 2009, 103.

118 Price 1794; Knight 1794; Klonk 1996, 9-11.

${ }^{119}$ Klonk 1996, 73 and 107. See e.g. Daniell 1818.

${ }^{120}$ RAA, LAW/3/60. Thomas Lawrence to Andrew Lawrence, 28 July 1819. Cited in Hoock 2003, 8.

${ }^{121}$ See Fleming 1934 on his relationship with Lawrence; Scott forthcoming 2013.

${ }^{122}$ Lysons possessed a copy of Joshua Reynolds's works (1798), no. 1207 in Evans 1820. Hoock 2003a, 1-3 on Reynolds' enthusiasm for British arts.
} 
exhibited drawings at the Royal Academy; these included landscapes, drawings of churches and castles, and his depiction of the Woodchester 'Great Pavement' in $1795 .{ }^{123}$

Throughout Lysons' works considerable emphasis is placed on the situations of the remains. Detailed maps recreate the ancient landscapes, showing the nature and quantity of Roman sites, for example in the vicinity of the Woodchester villa. They also demonstrate the impressive recording and mapping skills of Lysons and his associates; mapping was an essential 'expression of British national and imperial power' in the eighteenth century, and there was considerable competition between European nations in the recording of ancient landscapes as well as newly discovered territories. ${ }^{124}$ The influence of Lysons' geological interests is clear in the many meticulous section drawings and in the inclusion of detailed maps showing Roman sites within their landscape settings. ${ }^{125}$ Important advances were being made in the field of classical topography in this period, and Lysons' mapping skills were certainly equal to those of his better-known contemporaries; for example, his maps bear a striking resemblance to those of Sir William Gell. ${ }^{126}$

Descriptions and watercolours of sites situate the remains within the contemporary landscape, emphasising the picturesque beauty of the countryside and continuity with the classical past. In the Woodchester volume Lysons extols the beauty of the English landscape:

The beauty of the surrounding country must ... have been a considerable inducement to building here ... The spot of ground which was occupied by this edifice is sufficiently high to command a very beautiful prospect, yet not so elevated as to be deprived of the shelter afforded by the surrounding hills. It may reasonably be supposed, that, at the time when the building was erected, the country was more wooded than it is at present; there is still however a considerable portion of beech wood near the summit of the hills, which much

\footnotetext{
${ }^{123}$ Graves 1906, V, 121; Hoock 2003a, 47, 216-221.

${ }^{124}$ Sills 2007; Hoock 2010a, 213; see Hingley 2006 for the mapping of Roman Britain.

${ }^{125}$ Evans 2007, 193; Steer 1966; Scott forthcoming.

${ }^{126}$ for example, see Gell 1804; 1807; 1817-18; Hoock 2010a, 213.
} 
increases the beauty of the view. No place can enjoy a finer verdure, even in the driest seasons, than the valley of Woodchester. ${ }^{127}$

The landscape in the vicinity of the Woodchester villa, and the site of the discovery in particular, are further celebrated through the watercolour painting of the view from Selsley Hill looking across to the village of Woodchester (FIGURE 7). Woodchester village, and the path leading towards the village, are beautifully and dramatically lit by a shaft of sunlight, in a manner characteristic of picturesque painting in this period. ${ }^{128}$

In the view of Woodchester from Hampton Common (FIGURE 8), light strikes Woodchester Church with Hill House in the foreground. Hill House was owned at the time by Sir George Paul, the son of a wealthy cloth manufacturer, Sir Onesiphorus Paul, whose business was based at the Southfield Mill in the Parish of Woodchester. ${ }^{129}$

Harmonious 'classical' landscapes were often seen as contrasting with French superficiality and theatrical 'glitter', ${ }^{130}$ and Lysons' paintings convey an idyllic and picturesque landscape, dramatic lighting emphasising the beauty of the site of the Roman remains as well as the seat of an important local and national figure with royal connections; there is an almost timeless element to the scenes, stressing continuity with the classical past and directly challenging the notion that Britain's climate was incompatible with cultural and artistic achievement. That this was to some extent an idealised landscape is evident from contemporary maps, which show that the Rodborough parish was in fact an industrial 'hotspot' in this period, a renowned centre for the production of fine cloth. Eighteenth- and nineteenth-century maps show numerous mills along the river Frome (FIGURE 9). In the river valley close to Woodchester ran an important route where the Fleece Inn was opened in 1783 , built by Sir George Paul and other members of the local gentry, in order to provide a

\footnotetext{
${ }^{127}$ Lysons 1797, 18.

${ }^{128}$ See e.g. Daniell 1818.

${ }^{129}$ George III and Queen Charlotte breakfasted at Hill House on their visit to the area in 1788. Sir George became a well-known advocate for the reform of prisons and asylums (Hyett 1929). For a description of this visit, see letter from Samuel Lysons to Sir Joseph Banks, 18 August 1788, in Fleming $(1934,15)$.

${ }^{130}$ Harman 2009, 103; Hoock 2003a, 77; Smiles 2000.
} 
posting-house between Petty France and Gloucester; the inn was to become an important meetingplace for Gloucestershire clothiers. ${ }^{131}$ The Bear Inn, situated above Hill House, was opened in 1751 next to the Stroud-Cirencester turnpike. ${ }^{132}$ The landscape was therefore scattered with important roads, cloth mills, inns and farmsteads (for example at Achard's and Stringer's Court) and weavers' cottages (for example at Butter Row), as well as the houses of wealthy industrialists such as Hill House and Rodborough Folly, built by George Hawker (a wealthy mill owner) about 1764 . The industrial nature of the landscape is not evident in Lysons' paintings, where the viewpoints are carefully chosen to highlight the most picturesque and culturally significant elements, with the evidence for industry hidden in the valley below. It cannot be said that the landscape was inaccurately portrayed; but it was certainly strategically depicted. The paintings support Lysons' assertion that 'There is no situation, in the south-west parts of this island, which could have been more advantageous for the residence of any of the Roman governors than this place'. ${ }^{133}$

The views of Bignor are likewise carefully constructed (FIGURE 10), emphasising the scale of the remains and the beauty of the surrounding countryside; the estate of Bignor Park was owned by John Hawkins, the eminent traveller and geologist and close friend of Lysons. ${ }^{134}$ The villa blends seamlessly into the landscape; the view across the beautifully appointed dining-room to the countryside is enhanced by the avenue of trees, with Lysons (if it is he) contemplating the mosaic as the villa owner himself might have done. The painting supports Lysons' opinion that 'from the extent and magnificence of the apartments which it contained, no reasonable doubt can be entertained that it was the villa of some person of consequence, if not a public work, intended for the residence of the Propraetor, or the legate of governor of the province', ${ }^{135}$ or possibly for the eminent local leader, Cogidubnus. ${ }^{136}$ In general, Lysons assumes that villas were built by or for Romans from overseas, which is perhaps unsurprising given the dominant view that Britain was a military outpost;

\footnotetext{
${ }^{131}$ Herbert et al. 1976.

${ }^{132}$ Herbert et al. 1976.

133 Lysons 1797, 19.

134 Steer 1966; Torrens 2004.

${ }^{135}$ Lysons 1820, 33.

${ }^{136}$ Lysons 1817, 219; Hingley 2008, 255.
} 
the notion that the Bignor villa may have been built by or for a Briton is unusual in this period and directly challenges the dominant perception of Britain as a cultural backwater, suggesting in contrast a dramatic improvement from earlier barbarism. This image of Romans as civilizers is encapsulated in Addison's tragic play Cato (1713), which stressed that their 'genius [was] an atonement for their sword'. Britain might avoid the dangers of imperialism and despotism, which were seen as characteristic of Napoleon's attempts to establish Paris as a new Rome, through reflection on violence, corruption and moral decay, as emphasized by Cowper in his contemporary poem Boadicea: An Ode (1782). ${ }^{137}$

The achievements of Britons under Roman rule are similarly emphasised by Barnard, who argues that:

The conquest of the aspiring Romans laid the foundation, on which was gradually raised the glory of the Britons. From hence sprung, amidst the wilds of barbarism, a civilized nation ... wherin the arts and sciences have obtained their zenith of perfection. ${ }^{138}$

Lysons' volumes convey an impression of this harmonious and civilized environment which allowed the arts to flourish, and this is nowhere more evident than in his reconstruction of the temple at Bath, based on the drawings of Robert Smirke junior (architect of the British Museum) (FIGURE 11). ${ }^{139}$ The scene is populated with figures dressed in togas, socialising in the foreground; the sunlit classical façade stands out dramatically against the hills behind. The figures simultaneously emphasise the scale and grandeur of the buildings while implying continuity with the classical past, challenging earlier perceptions and conveying that Bath had been a beautiful and refined social and

\footnotetext{
${ }^{137}$ See Weinbrot 1993, 26-7. Cowper, W. 1980, Boadicea, an Ode, 431-2; Hingley and Unwin 2005, 150-3; Hingley 2008, 227. See also Hume (1763), who argued that Ireland's poor state resulted from the lack of a Roman invasion which would have brought order and civilization (see Weinbrot 1993, 27).

${ }^{138} 1790,12$.

${ }^{139}$ Lysons $1813, \mathrm{l}$, ii.
} 
cultural hub in the Roman period as it was in the eighteenth century. ${ }^{140}$ The importance of the site within the Roman period is further demonstrated by the accompanying quotation, carefully selected from Gaius Julius Solinus ( $3^{\text {rd }}$ century AD), who in chapter 22 of his Polyhistor describes the temple of Minerva at Bath: 'In this space (are) many great rivers, hot springs elaborated with opulent furnishings for the purposes of mortals' ${ }^{141}$ The fact that the importance of the temple was celebrated in antiquity lends further weight to Lysons' assertion that they equalled or surpassed those found elsewhere, placing Britain firmly at the heart of a shared classical heritage and directly challenging the notion that Britain's climate and character were incompatible with artistic and cultural achievement. ${ }^{142}$

\section{Conclusion: Lysons and his legacy}

As part of an intellectual elite genuinely concerned with developing and promoting British artistic and scientific achievements in a period of intense cultural rivalry, Lysons and his associates were keen to stimulate wider interest in their discoveries, to record remains accurately and to preserve them for the nation. His virtuosic display of erudite knowledge and artistic prowess can be seen as a statement of British cultural achievement both in the past and present. The careful use of comparative material showed that Britain had been a thoroughly civilised part of the Roman empire, sharing Continental artistic traditions and sometimes even artists, whose achievements rivalled those of their Continental counterparts and were limited only by the quality of materials to hand; even in cases where the quality of workmanship was less than impressive, it was possible to see the

\footnotetext{
${ }^{140}$ Sweet 2004, 185 on negative perceptions of discoveries at Bath. This appears to be the first reconstruction of life under Roman rule based on excavated remains.

${ }^{141}$ 'We learn that at the time when Solinus wrote, which is supposed to have been in the decline of the Roman empire, the hot springs in Britain (whereby unquestionably were intended those of Bath) were decorated with sumptuous buildings, for the benefit of mankind; that Minerva presided over these springs; that she had a temple near them, in which a perpetual fire was kept up; and that the fuel for the supply of this fire did not burn to a white ash, but, where the fire became extinct, was turned into stony balls; intimating no doubt the use of pit coal, the cinders of which must be meant by the stony balls, unlike the white ash produced by wood' (Lysons 1813, I, ii, 3, footnote f).

${ }^{142}$ The temple form is compared to remains found at Maison Quaree at Nimes and the arch of the Castell Vecchion at Verona (Reliquiae 1813, I, ii, 4).
} 
'graceful originals whence they were derived'. ${ }^{143}$ Landscape paintings, made at strategic viewpoints, dramatically emphasised continuity with this classical past.

While Lysons struggled to generate financial investment in the preservation and display of the discoveries, he was successful in attracting subscribers; he was a celebrated figure within intellectual and aristocratic circles, and his volumes came to be displayed alongside sumptuous volumes on classical antiquities, asserting Britain's place within a pan-European classical tradition. ${ }^{144}$

The need to assert British achievements in the excavation and publication of classical antiquities was particularly pressing in the period when travel to the Continent, and hence the collection of Mediterranean classical antiquities, was difficult, and when Napoleon was asserting his authority through the conspicuous acquisition and display of impressive examples of these. ${ }^{145}$ However, Lysons' interest in the preservation and recording of antiquities can also be seen as part of a wider aspiration, that of demonstrating Britain's cultural and moral superiority in the face of French bravura display and Napoleon's indiscriminate looting of Italian art and antiquities. His volumes showed that Britain had no need to appropriate antiquities from Italy, and that art objects were best appreciated and understood in their original contexts. ${ }^{146}$ Lysons did indeed hope that his Woodchester volume, a copy of which was sent to Napoleon, would promote similar scholarship in France; Francois Artaud published equally sumptuous volumes on the antiquities of Lyon, ${ }^{147}$ possibly inspired by Lysons' work and sent to the Englishman. ${ }^{148}$ It would be interesting to explore the reception and impact of Lysons' books in France through an evaluation of library collections and contemporary scholarship, as this would provide further insights into the nature of intellectual

\footnotetext{
${ }^{143}$ Reliquiae $1813, \mathrm{l}, \mathrm{l}$, advertisement.

${ }^{144}$ Aristocratic subscribers may also have benefited from an association with British talent and cultural achievement at a time when their lifestyles were being criticised in many circles as cosmopolitan, degenerate and superficial. See for e.g. Colley 1992, 169; Newman 1997; Hoock 2010a, 216.

${ }^{145}$ See Diaz-Andreu 2007, chapter 3; Gran-Aymerich 1998, 40.

146 Ramage 1992, 661; Hoock 2010, 207. The antiquarian Quatremère de Quincy (1755-1849) was critical of Napoleon's approach, and argued that art objects could not be fully appreciated unless they were in their original context (Gran-Aymerich 1998, 40).

${ }^{147}$ Artaud 1806.

${ }^{148}$ Only 20 copies of Artaud's work were produced; see for e.g. copy sold at auction, by Christie's in 2009, as part of a sale of Valuable Printed Books and Manuscripts, Including Fine Plate books from an Historic Continental Library (sale 7725, lot 193); for copies in Lysons' library see Evans 1820, no., 196.
} 
networks, international rivalry, and the ways in which cultural superiority was asserted and challenged through the excavation and publication of 'local' antiquities at a key period in the history of both archaeology and nationalism. ${ }^{149}$

Lysons assembled a collection of material from the villas at Woodchester, Bignor, Withington and Frampton, and presented it to the British Museum in 1808, 1810, 1811 and 1816 in the hope that it would be displayed in a dedicated gallery. ${ }^{150}$ His aspirations were not to achieve fruition until the mid-nineteenth century; ${ }^{151}$ rivalry with other European nations intensified and the Museum's interests were focused on the acquisition of classical antiquities on a grander scale, most notably Greek architectural sculpture but increasingly also the more exotic objects emanating from Egypt and the Near East. ${ }^{152}$ Romano-British art was often seen as a poor imitation of the art of Rome, which itself was increasingly viewed in an unfavourable light as the taste for Greek sculpture came to dominate. ${ }^{153}$ However, Lysons' publications did serve as a model for subsequent scholarship, most notably in the excavation and recording of villas and mosaics in Britain. ${ }^{154}$ They were also utilized in the assertion of regional identities; the Roman past was increasingly employed by local elites in order to enhance their prestige and maintain traditional social structures. ${ }^{155}$ For example, his role in demonstrating both the local and international significance of the remains of Roman Bath was celebrated by Joseph Hunter:

\footnotetext{
${ }^{149}$ See for e.g. Burn and Moore 2011, 399-415 on the Dam Hill bronzes and the importance of antiquarian networks in their recording and interpretation. Sweet 2004 on the importance of antiquarianism. On the importance of understanding the political, social and cultural context in which archaeology and nationalism emerged, see e.g. Diaz-Andreu 2007, 4.

${ }^{150}$ Fleming 1934, 37.

${ }^{151}$ Potter 1997.

152 Jenkins 1992; Moser 2006; Hoock 2010a. For military and diplomatic rivalry through archaeological enterprise and collecting, see for example, Hoock 2007; Jasanoff 2005. On the nineteenth-century 'chain of art', see Jenkins 1992, 56-74; Whitehead 2009. For an overview of Classical archaeology in this period, see Dyson 2006.

${ }^{153}$ See Henig 1995, 180-189 for an evaluation of attitudes to Romano-British art. See also Scott 2003 and 2006.

${ }^{154}$ See for example, Hakewill 1826 at North Leigh, Oxon and Artis 1828 on Roman remains in Northamptonshire and Leicestershire.

${ }^{155}$ On antiquarian societies and the importance of local pride and patriotism and the rise of professionalism see Hoselitz 2007, 52-80 and Levine 1986, 7-39.
} 
[these] have been illustrated most fully by a very eminent antiquary of the present age, whom we may claim as belonging to Bath, as many of his early years were spent here ... I mean the late Mr Samuel Lysons, who projected, and in part accomplished, one of the most magnificent works to be found in the literature of any nation ... There is a boldness of design about Reliquiae Romanae which excites the utmost respect and admiration; a carelessness of expense; a devotedness of heart to a project worthy of a great mind to entertain; and a taste and felicity in the execution, which mark the native and the cultivated elegance of his mind ... it also stands to the honour of Bath; for it is to Bath, which has treasured up so many of the remains of its former magnificence, that the world owes the conception of the grand design. ${ }^{156}$

Mosaics in particular continued to attract significant attention; they were 'classical', they often survived intact, and many impressive examples were dramatically uncovered in the nineteenth century. Lysons' publications, most notably his illustrations, were frequently employed in the elevation of their status to that of works of art worthy of study in their own right, and their excavation and study was often funded by those who had something to gain from the association; for example, in discussing the remains of Corinium (Cirencester, Gloucestershire), Buckman and Newmarch draw on the work of Lysons in order to demonstrate the achievements and refinements of earlier inhabitants:

The internal arrangements and decorations ever betokened the presidency of a spirit of elegance and refinement; and in no place in which it has been our lot to investigate the evidences of this are the proofs more convincing of the combination of comfort with good

\footnotetext{
${ }^{156}$ Connexion of Bath with the literature and science of England. Read before the Literary and Philosophical Association, Nov. 6, 1826, by the Rev. Joseph Hunter FAS. In The Sheffield Independent, and Yorkshire and Derbyshire Advertiser (Sheffield, England), Saturday, 30 December 1826, Issue 369.
} 
taste, of luxury with refinement, than is afforded by an examination of the internal ornamentation, which even yet remains to us of the Roman inhabitants of Corinium. ${ }^{157}$

The mosaics were appropriated by the influential local landowner Lord Bathurst, who exhibited far less interest in funding the recording or preservation of less dramatic discoveries. As in Lysons' time, the mosaic pavements were attractive because they represented links with a period of wealth and grandeur; they suited Bathurst's cosmopolitan tastes, enhancing his status within the town and further afield. ${ }^{158}$

The publications of Charles Roach Smith, which include excellent illustrations of mosaics, represent some of the finest scholarship on Roman Britain in the mid-nineteenth century; like Lysons, he took care to record all forms of evidence meticulously, and shared the conviction that the discoveries were of national significance and should be preserved. ${ }^{159}$ However, his painstaking approach, and his appreciation of the significance of all forms of evidence, were not characteristic of this period; for example, Morgan's 1886 volume was 'specially dedicated to the description of Romano-British mosaic pavements', ${ }^{160}$ and like Buckman and Newmarch he refers to the scholarship of Lysons in order to assert their aesthetic qualities, but he is less than enthusiastic about their pagan subject matter, and the quality of the illustrations and the standard of scholarship is far less impressive than those of Lysons or Roach Smith. ${ }^{161}$

Negative perceptions of Romano-British art dominated scholarship in the first half of the twentieth century; for example, Haverfield saw the adoption of Roman forms in Britain as an

\footnotetext{
${ }^{157}$ Buckman and Newmarch 1850, 25. The volume is dedicated to Lord Bathurst, and subscribers included the Prince Consort and the Archbishop of York. Like Lysons, they compared the remains to those found in Italy and elsewhere in order to demonstrate their artistic worth and hence the level of civilisation reached in the Roman period, although the standard of their scholarship is far less impressive (Buckman and Newmarch 1858, 46). See Henig 1995, 185-86 for an evaluation of their scholarship. On archaeological discoveries at Cirencester (Corinium) see Hoselitz 2007, 95-108.

${ }^{158}$ Hoselitz 2007, 108. See Henig 1995, 185 on their scholarship.

${ }^{159}$ See Henig 1995, 185-6 for an overview of his achievements in recording Romano-British art.

160 Morgan 1886. This volume includes a review of subject matter, an overview of scholarship and a description of discoveries by region. See Henig 1995, 187 for the broader context of his work and an evaluation of its significance.

${ }^{161}$ Morgan 1886, 277. See also Henig 1995, 186 and Hingley 2008, 307-8 on continuity between Roman and Saxon periods, and on his low opinion of pagan subject-matter.
} 
inevitable but somewhat uninspiring consequence of Romanisation $(1915,48) \cdot{ }^{162}$ It was not until the 1960s that the importance of all forms of Romano-British art was acknowledged; an exhibition of the art of Roman Britain held in Goldsmiths' Hall in London in July 1961 brought together a wide variety of Romano-British art for the first time. In the catalogue of the exhibition Jocelyn Toynbee enthuses about the overall impression created, which was 'that of an immensely rich intermingling in Britain of aesthetic tastes and standards, of patrons of very diverse types, and of subjects of widely differing kinds depicted in both native and imported works of art'; ${ }^{163}$ for example, the Aldborough Wolf and Twins mosaic, which is seen as 'almost comic in its extreme naivety', is depicted alongside the Woodchester Great Pavement, emphasizing this diversity. ${ }^{164}$

Since that time, interest in all forms of Romano-British art has developed, although the notion that art was somewhat peripheral to the more important mechanics of empire has often resulted in the neglect of such forms within general discussions. ${ }^{165}$ Roman Britain also remains at the margins of classical art scholarship. ${ }^{166}$ However, mosaics have continued to attract particular attention; an exemplary tradition of scholarship has developed over the past fifty years, ${ }^{167}$ and Lysons' work remains influential. ${ }^{168}$ The beautiful illustrations in the recent corpus of Romano-British mosaics are evocative of his publications, and the volumes include many examples of his engravings. The fourth century in particular is now seen as a 'Golden Age' in Roman Britain; as in Lysons' time, it

\footnotetext{
${ }^{162}$ See Henig 1995, 186-9 and Scott 2003 for overviews of attitudes to Romano-British art in this period. On Haverfield and Romanisation, see Hingley 2008, 321-5; Freeman 2007.

${ }^{163}$ Toynbee 1962, 1.

164 Toynbee 1962, nos 184 and 186. Despite the immense importance of this work, provincial art was still seen as a poor imitation of traditional Classical forms, demonstrating a lack of skill or understanding on the part of the artist or patron. In two volumes that appeared at this time Toynbee defined three basic categories of finds: high-quality art, imported from the Mediterranean area; high-quality provincial art, usually attributed to Gaulish artists; and low-quality art, usually produced by British craftsmen.

${ }^{165}$ See Scott 2003 for an overview. The subject has often been overlooked in general volumes on Roman Britain; for example, in Wacher's Roman Britain (1978) there is virtually no mention of art, and in Salway's (1984) volume the only discussion is a small section on mosaics. Mattingly 2006 discusses visual representation in relation to different communities in Britain in the Roman period, but there is no detailed evaluation. See Stewart 2010 on provincialism.

${ }^{166}$ On the marginalization of Romano-British archaeology in the context of Classical scholarship see Henig 2004, 134. See also Stewart 2010.

167 The work of French scholars in Algeria, Morocco and Tunisia was important in stimulating interest in mosaics. See Ling 2001 for an overview.

${ }^{168}$ See Henig 1995; Ling 1997; Scott 2000 and Witts 2005 for reviews of this scholarship.
} 
is argued that artistic accomplishments rivalled those on the Continent and should be valued as highly as these, although distinctively 'British' characteristics are now celebrated. ${ }^{169}$ It is essential that we reflect on how and why we continue to prioritise and evaluate mosaics and other 'classical' forms if we are to promote the study of other types of visual culture, and in particular the relationships between them. ${ }^{170}$ In moving beyond the identification of certain forms of material culture as more or less Roman, it is possible to explore complex patterns of similarity and difference. ${ }^{171}$

There is also huge scope for understanding better the ways in which 'local' antiquities were employed in the negotiation of national identities in Britain and Continental Europe in the more recent past; as argued by Diaz-Andreu, the majority of scholarship on nationalism in the nineteenth century has focused on the latter part of the century since the term was little used before this period. ${ }^{172}$ It is important, however, to explore the close relationship between archaeology and the emergence of nationalism at this formative period in the history of the discipline. The potential of such an approach is clear: the achievements of Samuel Lysons and his associates are scarcely known outside of the field of Romano-British archaeology, yet close scrutiny of their work, and its wider context, shows that they were working collaboratively to an international agenda, and that their efforts were supported and celebrated by their contemporaries. The study of Romano-British archaeology is of equal importance to the study of Mediterranean classical antiquities in every respect.

\footnotetext{
169 Henig 1995, 138-73 asserts the variety and quality of artistic achievement in fourth-century Britain, challenging negative perceptions of Romano-British art and the notion that the quality of art declined in the later empire.

${ }^{170}$ On the importance of 'art' in the context of colonial encounters, see for example Thomas and Losche 1999. On the importance of reflecting on the classification of objects as art, see for example Vogel 1988. On provincialism, see Stewart 2010.

${ }^{171}$ See for example, Hill 2001; Mattingly 1997; 2002; 2004; 2006; Roth and Keller 2007; van Dommelen and Terrenato 2007; Revell 2009 on local responses to Roman imperialism. On the importance of deconstructing the term Roman, see Revell 2009, $x$.

${ }^{172}$ Diaz-Andreu 2007, 4.
} 


\section{Acknowledgements}

I am very grateful to Professors Lin Foxhall, Graham Shipley, Rosemary Sweet, Dr Penelope Allison and the anonymous reviewers for their comments on earlier drafts of this paper, and to Revd.

Professor Martin Henig for his kind support and encouragement. 


\section{Bibliography}

Primary Sources

A Catalogue of the library of the late Sir H.C. Englefield, Bart. Comprising an extensive and very valuable collection of books in history, antiquities, natural and experimental philosophy, arts, sciences, voyages, travels and general literature. Which will be sold by auction by Mr. Stanley, at his gallery in Maddox St, Hanover Square, on Monday, the $6^{\text {th }}$ of May 1833, and seven following days (Sunday excepted).

An inventory of paintings, drawings and furniture belonging to Samuel Lysons, which lists items in the 'Little Room' and Library with valuations, including several paintings and drawings by Sir Thomas Lawrence. National Portrait Gallery, Collected Archives, MS163.

Catalogue of First Day of Sale of Prints, Drawings and Books of Prints (Queen Charlotte's Library), which took place in June 1819 under the hammer of Mr Christie.

EVANS, S.C., 1820. A catalogue of the valuable and extensive library of the late Samuel Lysons esq. FRS and FAS, Keeper of Records in the Tower, containing an excellent collection of topography, history, antiquity, voyages, travels, and miscellaneous literature, which will be sold by auction by $\mathrm{Mr}$ Evans, at his house No. 96 Pall Mall, on Monday June 5th, and seven following days (Sunday excepted).

Morning Chronicle, Monday June 9, 1806, issue 11563

Oracle and Public Advertiser, London, Monday 23 Apr. 1798, issue 19916.

PHILLIPS, 1823. A catalogue of the magnificent, rare and valuable library of books in Fonthill Abbey.

Vetusta Monumenta 1815, Volume IV. Society of Antiquaries: London. 


\section{Secondary Sources}

ARNOLD, D. and BENDING, S., 2002. Tracing architecture: the aesthetics of antiquarianism. Art History, 25(4), pp. 421-430.

ARTAUD, F. 1806. Mosaiques de Lyon et des Départemens Meridionaux de la France. Lyons:

Ballanche.

ARTAUD, F. 1806. Description d'une Mosaique representant de Jeux du Cirque. Lyons: Ballanche.

ARTIS, E., 1828. The Durobrivae of Antoninus identified and illustrated in a series of plates, exhibiting the excavated remains of that Roman station, in the vicinity of Castor, Northamptonshire, discovered by E.T. Artis. London.

AYRES, P., 1997. Classical culture and the idea of Rome in eighteenth-century England. Cambridge:

Cambridge University Press.

BADDELEY, W.S.C., 1926. The Roman pavement at Woodchester. Transactions of the Bristol and Gloucestershire Archaeological Society, 48, pp. 75-96.

BAIRD, J. and RYSKAMP, C., (eds) 1980. The poems of William Cowper, Volume 1: 1748-1782.

BALLANTYNE, A., 2002. Specimens of Antient Sculpture: Imperialism and the decline of art. Art History, 24, 4, pp. 550-565.

BARRY, J., 1798. A letter to the Dilettanti Society. London.

BAYLEY, J., 1821. The history and antiquities of the Tower of London: With biographical anecdotes of royal and distinguished persons, deduced from records, state papers ... and from other original and authentic sources. London.

BARNARD, E., 1790. The new, comprehensive, impartial and complete history of England: From the very earliest period of authentic information, to the end of the present year. London. 
BESTERMAN, T., 1938. The publishing firm of Cadell \& Davies: Select correspondence and accounts, 1793-1836. Oxford: Oxford University Press.

BOHN, H., 1841. A catalogue of books, volume 1. London.

BRAND, V., 1998. The study of the past in the Victorian age. Oxford: Oxbow Books.

BRAYSHAY, M., 1996. Topographical writers in south-west England. Exeter: University of Exeter Press.

BRYLOWE, T., 2008. Two kinds of collections: Sir William Hamilton's vases, real and represented. Eighteenth-Century Life, 32(1), pp. 23-56.

BUCKMAN, J. and NEWMARCH, C.H., 1850. Illustrations of the remains of Roman art in Cirencester: the site of ancient Corinium. London: George Bell.

BURKE, E., 1820. The annual register, or, a view of the history, politics, literature for the year 1819. London: Baldwin, Cradock and Joy.

BURN, L. and MOORE, N. 2011. The Dam Hill bronzes. Journal of the History of Collections 24, 3, 399415.

CAMDEN, W., 1695. Camden's Britannia 1695: A facsimile of the 1695 edition published by Edmund Gibson (reprinted Newton Abbot, 1971).

CARTER, H.B., 1988. Sir Joseph Banks, 1743-1820. London: British Museum (Natural History).

CAYGILL, M. and CHERRY, J., eds, 1997. A.W. Franks: Nineteenth-century collecting and the British Museum. London: British Museum Press.

CAYLUS, COMPTE DE, 1752, 1756, 1759, 1761, 1762, 1764, 1767. Recueil d' antiquités Egyptiennes, Etrusques, Grecques et Romaines, 7 vols. Paris. 
CLARKE, G., SHEPHERD, J.D. and RIGBY, V., 1982. The Roman villa at Woodchester. Britannia, 13, pp. $197-228$.

COLLEY, L., 1992a. Britons: Forging the nation 1707-1837. 4 edn. New Haven and London: Yale University Press.

COLLEY, L., 1992b. Britishness and otherness: An argument. Journal of British Studies, 31(4), pp. 309329.

COLLEY, L., 1986. Whose nation? Class and national consciousness in Britain, 1750-1830. Past and Present, 113, pp. 97-117.

COLLEY, L., 1984. The apotheosis of George III: Loyalty, royalty and the British nation, 1760-1820. Past and Present, 102, pp. 94-129.

COLTMAN, V., 1999. Classicism in the English library. Reading classical culture in the late eighteenth and early nineteenth centuries. Journal of the History of Collections, 11(1), pp. 35-50.

COOK, J. and KING, J., 1785. A voyage to the Pacific Ocean: Undertaken by the command of His Majesty, for making discoveries in the Northern Hemisphere ... in the years 1776, 1777, 1778, 1779, and 1780... London: Printed by H. Hughes, for G. Nicol and T. Cadell.

COSH, S.R. and NEAL, D., 2010. Roman mosaics of Britain, Volume IV: Western Britain, including Wales. London: Illuminata Publishers for the Society of Antiquaries of London.

CRASKE, M., 1997. Art in Europe, 1700-1830: A history of the visual arts in an era of unprecedented urban economic growth. Oxford: Oxford University Press.

DANIELL, W., 1818. Illustrations of the Island of Staffa in a series of views: Accompanied by topographical and geological description. London. 
DAVY, H., 1817. Observations upon the composition of the colours found on the walls of the Roman house discovered at Bignor in Sussex. in a letter to Samuel Lysons, Esq. V. P. Archaeologia, 18, pp. 222.

DAVY, H., 1815. Some experiments and observations on the colours used in painting by the ancients. Philosophical Transactions of the Royal Society of London, 105, pp. 97-124.

DIAZ-ANDREU, M. 2007. A world history of nineteenth-century archaeology: Nationalism, colonialism and the past. Oxford: Oxford University Press.

DUBOS, A.J.B., 1719. Reflexions critiques sue le poesie et sur la peinture. Paris.

DYSON, S.L., 2006. In pursuit of ancient pasts: $A$ history of classical archaeology in the nineteenth and twentieth centuries. New Haven: Yale University Press.

EAGLES, R., 1997. Beguiled by France? The English aristocracy, 1748-1848. In: L. BROCKLISS and D. EASTWOOD, eds, A union of multiple identities: The British Isles, c.1750-c.1850. Manchester: Manchester University Press, pp. 60-77.

EMILIA MASCI, M., 2007. The birth of ancient vase collecting in Naples in the early eighteenth century: Antiquarian studies, excavations and collections. Journal of the History of Collections 19: 215-224.

ESSEX, J., 1774. Remarks on the antiquity and the different modes of brick and stone buildings in England. Archaeologia 4, 73-109.

EVANS, J., 1956. History of the Society of Antiquaries. Oxford: Oxford University Press.

FISKE, T., 2004. "Smirke, Robert (1753-1845)." Tina Fiske In Oxford Dictionary of National Biography, online ed., edited by Lawrence Goldman. Oxford: OUP, http://www.oxforddnb.com/view/article/25762 (accessed October 1, 2012). 
FLAXMAN, J., 1799. A Letter to the Committee for raising the Naval Pillar or Monument under the patronage of his Highness the Duke of Clarence, Dec. 1799. Reprinted in J. Physick 1969, Designs for British Sculpture 1680-1860, 169.

FLEMING, L., 1934. Memoir and select letters of Samuel Lysons, 1763-1819. Oxford: Johnson.

FREEMAN, P., 2007. The best training-ground for archaeologists: Francis Haverfield and the invention of Romano-British archaeology. Oxford: Oxbow.

FRERE, S., 1982. The Bignor villa. Britannia, 13, pp. 135-195.

FRESHWATER, T., DRAPER, J., HENIG, M. and HINDS, S., 2000. From stone to textile: The Bacchus mosaic at Stonesfield Oxon., and the Stonesfield embroidery. Journal of the British Archaeological Association 153, 1-29.

GAIMSTER, D., MCCARTHY, S. and NURSE, B., eds, 2007. Making history: Antiquaries in Britain 17072007. London: Royal Academy of Arts.

GALE, R., 1739. Roger Gale to Dr Stukeley, concerning Roman pavements. In: W.C. LUKIS, ed, The family memoirs of the Rev. William Stukeley, M.D. and the antiquarian and other correspondence of William Stukeley, Roger and Samuel Gale etc. Volume 3, 1887 edn. Durham: Surtees Society, Vol. 80, pp. 41-42.

GARLICK, K., 1954. Sir Thomas Lawrence. London: Routledge \& Paul

GASCOIGNE, J., 2004. "Banks, Sir Joseph, baronet (1743-1820)." John Gascoigne In Oxford Dictionary of National Biography, edited by H. C. G. Matthew and Brian Harrison. Oxford: OUP, 2004. Online ed., edited by Lawrence Goldman, May 2009. http://www.oxforddnb.com/view/article/1300 (accessed October 1, 2012).

GASCOIGNE, J., 1998. Science in the service of empire: Joseph Banks, the British state and the uses of science in the age of revolution. Cambridge: Cambridge University Press. 
GOODWIN, G. 2004. "Lysons, Samuel (bap. 1763, d. 1819)." Rev. Brian Frith. In Oxford Dictionary of National Biography, edited by H. C. G. Matthew and Brian Harrison. Oxford: OUP, 2004. Online ed., edited by Lawrence Goldman, http://www.oxforddnb.com/view/article/17298 (accessed October 1, 2012).

GRAN-AYMERICH, E. 1998. Naissance de l'archeologie modern 1798-1945. Paris: CNRS.

GRAVES, A., 1970. The Royal Academy of Art: A complete dictionary of contributors and their work from its foundation in 1769 to 1904. East Ardsley: Kingsmead Reprints.

HAKEWILL, H., 1826. An account of the Roman villa discovered Northleigh Oxfordshire in the years $1813,1814,1815,1816$.

HAMILTON, W. 1776. Account of the discoveries at Pompeii, communicated by Sir William Hamilton. Archaeologia, 4, pp. 160-175.

HARMAN, P.M., 2009. The culture of nature in Britain 1680-1860. New Haven, Conn: Yale University Press.

HASKELL, F., 1993. History and its images: Art and the interpretation of the past. New Haven, Conn: Yale University Press.

HAYLEY, W. 1800. An essay on sculpture. Literature Online, http://lion.chadwyck.co.uk. Accessed 11 Feb 2013.

HENIG, M., 2004. A house divided: The study of Roman art and the art of Roman Britain. In: E. SAUER, ed, Archaeology and Ancient History: Breaking down the boundaries. London: Routledge, pp. $134-150$.

HENIG, M. and BOOTH, P., 2000. Roman Oxfordshire. Stroud: Sutton.

HENIG, M., 1995. The art of Roman Britain. London: B.T. Batsford. 
HERBERT, N.M., PUGH, R.B., BAGGS, A.P., JURICA, A.R.J. and SHEILS, W.J., 1976. A history of the County of Gloucester: Bisley and Longtree Hundreds: Rodborough: Introduction. http://www.britishhistory.ac.uk/report.aspx?compid=19118. Accessed $7^{\text {th }}$ October 2012.

HERENDEEN, W. H., “Camden, William (1551-1623)." Wyman H. Herendeen In Oxford Dictionary of National Biography, edited by H. C. G. Matthew and Brian Harrison. Oxford: OUP, 2004. Online ed., edited by Lawrence Goldman, January 2008. http://www.oxforddnb.com/view/article/4431 (accessed March 30, 2013).

HINGLEY, R. 2008. The recovery of Roman Britain 1586-1906: A colony so fertile. Oxford: Oxford University Press.

HINGLEY, R., 2006. Projecting empire: The mapping of Roman Britain. Journal of Social Archaeology, 6(3), pp. 328-353.

HINGLEY, R., 2000. Roman officers and English gentlemen: The imperial origins of Roman archaeology. London: Routledge.

HINGLEY, R. AND UNWIN, C., 2005. Boudica: Iron age warrior queen. Hambledon: London. HOARE, R.C., SIR, 1822. The modern history of South Wiltshire. London: Nichols and Nichols. HOOCK, H., 2010a. Empires of the imagination: Politics, war, and the arts in the British world, 17501850. London: Profile Books Ltd.

HOOCK, H., 2010b. "Struggling against a vulgar prejudice": Patriotism and the collecting of British art at the turn of the nineteenth century. Journal of British Studies, 49(3), pp. 566-591.

HOOCK, H., 2007. The British State and the Anglo-French wars over antiquities, 1798-1858. The Historical Journal, 50(1), pp. 49-72. 
HOOCK, H., 2003a. The King's artists: The Royal Academy of Arts and the politics of British culture 1760-1840. Oxford: Clarendon Press.

HOOCK, H., 2003b. From Beefsteak to Turtle: Artists' dinner culture in eighteenth-century London. The Huntington Library Quarterly, 66(1/2), pp. 27-54.

HOSELITZ, V., 2007. Imagining Roman Britain: Victorian responses to a Roman past. London: Royal Historical Society.

HYETT, F., 1929. Sir George Onesiphorus Paul. Transactions of the Bristol and Gloucestershire Archaeological Society, 51, pp. 143-168.

JASANOFF, M., 2005. Edge of empire: Conquest and collecting in the east, 1750-1850. London: Harper Perennial.

JENKINS, I., 1992. Archaeologists and aesthetes in the sculpture galleries of the British Museum, 1800-1939. London: British Museum Press.

JENKINS, I. and SLOAN, K., 1996. Vases and volcanoes: Sir William Hamilton and his collection. London: Published for the Trustees of the British Museum by the British Museum Press.

JOHNS, C., 2001. Samuel Lysons, FRS, FSA (1763-1819). Joint Association of Classical Teachers Review, 29 (Summer), pp. 3.

KIDD, C., 1999. British identities before nationalism: Ethnicity and nationhood in the Atlantic world, 1600-1800. Cambridge: Cambridge University Press.

KIDD, C., 1996. North Britishness and the nature of eighteenth-century British patriotism. Historical Journal, 39(2), pp. 361-382. 
KLONK, C., 1996. Science and the perception of nature: British landscape art in the late eighteenth and early nineteenth centuries. Paul Mellon Centre for Studies in British Art. New Haven and London: Yale University Press.

KNIGHT, D., 2004. “Davy, Sir Humphry, baronet (1778-1829)." David Knight In Oxford Dictionary of National Biography, edited by H. C. G. Matthew and Brian Harrison. Oxford: OUP, 2004. Online ed., edited by Lawrence Goldman, January 2011. http://www.oxforddnb.com/view/article/7314 (accessed October 1, 2012).

KNIGHT, R.P., 1794. The landscape: A didactic poem. London.

KNIGHT, R.P., 1809. Specimens of antient sculpture. Selected from different collections of Great Britain, by the Society of Dilettanti. London.

KURTZ, D., 2000. The Reception of Classical Art in Britain. Studies in the History of Collections. Oxford: Archaeopress.

KURTZ, D., ed. 2004. The Reception of Classical Art: An Introduction. Studies in Classical Greece. Oxford: Archaeopress.

LANGFORD, P., 2004. "Walpole, Horatio, fourth earl of Orford (1717-1797)." Paul Langford In Oxford Dictionary of National Biography, edited by H. C. G. Matthew and Brian Harrison. Oxford: OUP, 2004. Online ed., edited by Lawrence Goldman, May 2011.

http://www.oxforddnb.com/view/article/28596 (accessed October 1, 2012).

LEVEY, M. 2004. "Lawrence, Sir Thomas (1769-1830)." Michael Levey In Oxford Dictionary of National Biography, edited by H. C. G. Matthew and Brian Harrison. Oxford: OUP, 2004. Online ed., edited by Lawrence Goldman, May 2011. http://www.oxforddnb.com/view/article/16189 (accessed October 1, 2012).

LEVEY, M., 1979. Sir Thomas Lawrence, 1769-1830. London: National Portrait Gallery. 
LEVINE, J.M., 1978. The Stonesfield pavement: Archeology in Augustan England. Eighteenth-Century Studies, 11(3), pp. 340-361.

LE BLANC, A. 1747. Letters on the English and French nations, 2 vols.

LEVINE, P., 1986. The amateur and the professional: Antiquarians, historians and archaeologists in Victorian England, 1838-1886. Cambridge: Cambridge University Press.

LINDLEY, P., 2012. The artistic practice, protracted publication and posthumous completion of Charles Alfred Stothard's Monumental Effigies of Great Britain. The Antiquaries Journal, 92, pp. 385426.

LING, R., 2001. Roman mosaics: A success story of classical archaeology. American Journal of Archaeology, 105, pp. 325-329.

LOWNDES, W., 1834. The bibliographer's manual of English literature, Vol. III. London: William Pickering.

LOWNDES, W.T. and BOHN, H.G., 1890. The bibliographer's manual of English literature ... London: George Bell.

LYSONS, S., 1820. An account of the remains of a Roman villa discovered at Bignor, in the county of Sussex: in the year 1811, and four following years. London: Printed by T. Bensley ... : Sold by T. Cadell and W. Davies ..., and by G. Tupper, of Bignor.

LYSONS, S., 1817a. Reliquiae Britannico-Romanae: containing figures of Roman antiquities discovered in various parts of England, Volume II. London: Printed by T. Bensley, and sold by Messrs. Cadell and Davies, T. Payne, and White, Cochran, and Co.

LYSONS, S., 1817b. Reliquiae Britannico-Romanae: containing figures of Roman antiquities discovered in various parts of England, Volume III. London: Printed by T. Bensley, and sold by Messrs. Cadell and Davies, T. Payne, and White, Cochran, and Co. 
LYSONS, S., 1813. Reliquiae Britannico-Romanae: containing figures of Roman antiquities discovered in various parts of England, Volume I. London: Printed by T. Bensley, and sold by Messrs. Cadell and Davies, T. Payne, and White, Cochran, and Co.

LYSONS, S., (1803 or 1804). A collection of Gloucestershire antiquities. London.

LYSONS, S., 1797. An account of Roman antiquities discovered at Woodchester in the county of Gloucester. London: Cadell and Davies.

MARCHAND, S.L., 2003. Down from Olympus: Archaeology and philhellenism in Germany, 1750-1970. Princeton, N.J: Princeton University Press.

MATTINGLY, D., 2004. Being Roman: Expressing identity in a provincial setting. Journal of Roman Archaeology, 17, pp. 5-25.

MATTINGLY, D., 2002. 'Vulgar and weak Romanization,' or time for a paradigm shift. Journal of Roman Archaeology, 15, pp. 536-540.

MATTINGLY, D., 1997. Dialogues of power and experience in the Roman empire. In: D. MATTINGLY, ed, Dialogues in Roman imperialism: Power, discourse, and discrepant experience in the Roman empire. Supplement 23. Portsmouth: Journal of Roman Archaeology, pp. 7-26.

MATTINGLY, D.J., 2010. Imperialism, power, and identity: Experiencing the Roman empire. Woodstock: Princeton University Press.

MATTINGLY, D.J., 2006. An imperial possession: Britain in the Roman Empire, 54 BC-AD 409. London: Allen Lane.

McCONNELL, A., 2004. “Fowler, William (1761-1832)." Anita McConnell In Oxford Dictionary of National Biography, edited by H. C. G. Matthew and Brian Harrison. Oxford: OUP, 2004. Online ed., edited by Lawrence Goldman, January 2008. http://www.oxforddnb.com/view/article/10016 (accessed October 1, 2012). 
MONTESQUIEU, C.L., 1748 (1751). The spirit of laws. Translated from the French ... with corrections and additions communicated by the author, 2 vols. Dublin.

MONTFAUCON, B. DE. 1722-24. L'Antiquite expliquee et representee en figures (seconde edition, revue et corrigee). Paris

MORGAN, T., 1886. Romano-British mosaic pavements: A history of their discovery and a record and interpretation of their designs. London: Whiting.

MOSER, S., 2006. Wondrous curiosities: Ancient Egypt at the British Museum. Chicago: University of Chicago Press.

MYRONE, M. and PELTZ, L., 1999. Producing the past: Aspects of antiquarian culture and practice, 1700-1850. Aldershot: Ashgate.

NEAL, D. and COSH, S.R., 2008. Roman mosaics of Britain, Volume III: South-east Britain. London: Illuminata Publishers for The Society of Antiquaries of London.

NEAL, D. and COSH, S.R., 2005. Roman mosaics of Britain, Volume II: South-west Britain. Illuminata Publishers for The Society of Antiquaries of London.

NEAL, D. and COSH, S.R., 2002. Roman mosaics of Britain, Volume I: Northern Britain, incorporating the Midlands and East Anglia. London: Illuminata Publishers for The Society of Antiquaries of London.

NEWBY, E. 2004. “Farington, Joseph (1747-1821)." Evelyn Newby In Oxford Dictionary of National Biography, online ed., edited by Lawrence Goldman. Oxford: OUP, http://www.oxforddnb.com/view/article/9161 (accessed October 1, 2012).

NEWBY, E., ed, 1998. The diary of Joseph Farington. New Haven: Yale University Press for the Paul Mellon Centre for Studies in British Art. 
NEWMAN, G., 1997. The rise of English nationalism: A cultural history, 1740-1830. Basingstoke: Macmillan.

NURSE, B. and CROOK, J.M., 2011. John Carter, FSA (1748-1817): 'The Ingenious, and Very Accurate Draughtsman'. The Antiquaries Journal, 91, pp. 211-252.

NURSE, B. 2007., Bringing truth to light. In: D. GAIMSTER, S. MCCARTHY and B. NURSE, eds, Making history: Antiquaries in Britain 1707-2007. London: Royal Academy of Arts, pp. 143-161.

OATES, J., 1972. Cambridge University and the Reform of the Copyright Act, 1805-1813. The Library, XXVII(4), pp. 275-292.

PARSLOW, C., 1998. Rediscovering antiquity: Karl Weber and the excavation of Herculaneum, Pompeii, and Stabiae. Cambridge University Press: Cambridge.

PEARCE, S., eds, 2007. Society of Antiquaries of London. Visions of antiquity: The society of antiquaries of london 1707-2007. Society of Antiquaries of London: London.

POTTER, T., 1997. Later prehistory and Roman Britain: the formation of the national collections. In:

M. CAYGILL and J. CHERRY, eds, A. W. Franks: Nineteenth-century collecting and the British Museum. London: British Museum Press, pp. 130-135.

POWNALL, T., 1795. Description and explanations of some remains of Roman antiquities dug up in the city of Bath, in the year MDCCXC with an engraving from drawings made on the spot. London.

PRICE, U., 1794. An essay on the picturesque, as compared with the sublime and the beautiful. London.

PHYSICK, J., 1969, Designs for British sculpture 1680-1860. London.

RAMAGE, N., 1992. Goods, graves and scholars: 18th-century archaeologists in Britain and Italy. American Journal of Archaeology, 96(4), pp. 653-661. 
REES-JONES, S., 1990. Early experiments in pigment analysis. Studies in Conservation, 35, No. 2, pp. 93-101.

REVELL, L., 2009. Roman imperialism and local identities. Cambridge: Cambridge University Press.

RICHARDSON, R., 2004. William Camden and the re-discovery of England. Transactions of the Leicestershire Archaeological and Historical Society, 78, 108-23.

RICHTER, A., 2008. Spectacle, exoticism and display in the gentleman's house: The Fonthill auction of 1822. Eighteenth - Century Studies, 41, 4, 543-563.

RIDDELL, R., 2004. "Smirke, Sir Robert (1780-1867)." Richard Riddell In Oxford Dictionary of National Biography, edited by H. C. G. Matthew and Brian Harrison. Oxford: OUP, 2004. Online ed., edited by Lawrence Goldman, May 2010. http://www.oxforddnb.com/view/article/25763 (accessed October 1, 2012).

ROACH SMITH, C., 1859. Illustrations of Roman London. London.

ROACH SMITH, C., 1848. Collectanea antiqua: etchings and notices of ancient remains, illustrative of the habits, customs, and history of past ages. London.

ROOKE, H., 1787. An account of the remains of two Roman villae discovered near Mansfield Woadhouse, in May and October, 1786. Archaeologia, 8, pp. 363-376.

ROY, W., 1793. The military antiquities of the Romans in Britain. London.

ROTH, R. and KELLER, J., 2007. Roman by integration: Dimensions of group identity in material culture and text. Supplement 63. Portsmouth: Journal of Roman Archaeology.

SALWAY, P., 1984. Roman Britain. Oxford: Oxford University Press.

SAUER, E., ed, 2004. Archaeology and Ancient History: Breaking down the boundaries. London: Routledge. 
SCHMIDT, SEIGNEUR DE ROSSAN, MR., 1771. Recueil D'Antiquites de la Suisse. Frankfurt.

SCOTT, J., 2003. The pleasures of antiquity: British collectors of Greece and Rome. New Haven: Yale University Press for the Paul Mellon Centre for Studies in British Art.

SCOTT, S. 2013a. Art, archaeology and science: Samuel Lysons and remains of Roman Britain. Forthcoming in Bulletin of the History of Archaeology.

SCOTT, S. 2013b. Pioneers, publishers and the dissemination of archaeological knowledge: A study of publishing in archaeology 1816-1851. Forthcoming in Internet Archaeology.

SCOTT, S., 2006. Art and the archaeologist. World Archaeology, 38(4), pp. 628-643.

SCOTT, S., 2003. Provincial art and Roman imperialism: An overview. In: S. SCOTT and J. WEBSTER, eds, Roman imperialism and provincial art. Cambridge: Cambridge University Press, pp. 1-7.

SCOTT, S., 2000. Art and society in fourth-century Britain: villa mosaics in context. Oxford: Oxford University School of Archaeology.

SHER, R., 2006. The Enlightenment and the book: Scottish authors and their publishers in eighteenthcentury Britain, Ireland and America. Chicago: University of Chicago Press.

SILLS, A., 2007. Eighteenth - century cartographic studies: A brief survey. Literature Compass, 4(4), pp. 981-1002.

SMILES, S., 2007. The art of recording. In: D. GAIMSTER, S. MCCARTHY and B. NURSE, eds, Making history: Antiquaries in Britain 1707-2007. London: Royal Academy of Arts, pp. 123-141.

SMILES, S. 2000. Rural scenes and national representation: Britain 1815-1850. Journal of Historical Geography, 26(1), pp. 139.

SMILES, S., 1994. The image of antiquity: ancient Britain and the romantic imagination. New Haven: Yale University Press for the Paul Mellon Centre for Studies in British Art. 
SMITH, G., 2002. The emergence of the professional watercolourist. Aldershot: Ashgate.

STEER, F.W., ed, 1966. The letters of John Hawkins and Samuel and Daniel Lysons, 1812-1830, with special reference to the Roman villa at Bignor, Sussex. Chichester: West Sussex County Council.

STEWART, P., 27 July 2010. Geographies of provincialism in Roman sculpture. URL: http://www.rihajournal.org/articles/2010/stewart-geographies-of-provincialism. Accessed $6^{\text {th }}$ October 2012.

STUART, J. and REVETT, N., 1762-1816. The Antiquities of Athens, 4 vols. Society of Dilettanti: London.

SULLIVAN, M. G., 2004. “Stothard, Thomas (1755-1834).” M. G. Sullivan In Oxford Dictionary of National Biography, edited by H. C. G. Matthew and Brian Harrison. Oxford: OUP, 2004. Online ed., edited by Lawrence Goldman, September 2012. http://www.oxforddnb.com/view/article/26603 (accessed October 1, 2012).

SWEET, R., 2004a. Antiquaries: The discovery of the past in eighteenth-century Britain. London: Hambledon.

SWEET, R., 2004b. “Gough, Richard (1735-1809)." R. H. Sweet In Oxford Dictionary of National Biography, edited by H. C. G. Matthew and Brian Harrison. Oxford: OUP, 2004. Online ed., edited by Lawrence Goldman, October 2008. http://www.oxforddnb.com/view/article/11141 (accessed October 1, 2012).

SWEET, R., 2001. Antiquaries and antiquities in eighteenth-century England. Eighteenth - Century Studies, 34(2), pp. 181-206.

SYMMONS, S., 2004. "Flaxman, John (1755-1826)." Sarah Symmons In Oxford Dictionary of National Biography, edited by H. C. G. Matthew and Brian Harrison. Oxford: OUP, 2004. Online ed., edited by Lawrence Goldman, January 2008. http://www.oxforddnb.com/view/article/9679 (accessed October 1, 2012) 
THOMAS, N. and LOSCHE, D., eds, 1999. Double vision: Art histories and colonial histories in the Pacific. Cambridge: Cambridge University Press.

THORNTON, R.J., 1799-1807. The Temple of Flora. London: Cadell and Davies.

TODD, M., 2004. The rediscovery of Roman Britain. In: M. TODD, ed, A Companion to Roman Britain. Oxford: Wiley Blackwell, pp. 443-459.

TODD, M., 1996. From romanticism to archaeology: Richard Colt Hoare, Samuel Lysons and antiquity. In: M. BRAYSHAY, ed, Topographical writers in south-west England. Exeter: University of Exeter Press, pp. 90-104.

TORRENS, H. S., 2004. “Hawkins, John (1761-1841)." H. S. Torrens In Oxford Dictionary of National Biography, online ed., edited by Lawrence Goldman. Oxford: OUP, http://www.oxforddnb.com/view/article/12675 (accessed October 1, 2012).

TOYNBEE, J., 1964. Art in Britain under the Romans. Oxford: Clarendon Press.

TOYNBEE, J., 1962. Art in Roman Britain. London: Phaidon.

UPEX, S.,2001. The Roman villa at Cotterstock, Northamptonshire. Britannia 32, 57-92.

VAN DOMMELEN, P. and TERRENATO, N., eds, 2007. Articulating local cultures: Power and identity under the expanding Roman Republic. Supplement 63. Portsmouth: Journal of Roman Archaeology.

VOGEL, S., 1988. ART/Artifact: African art in anthropology collections. New York: Museum for African Art.

WACHER, J., 1978. Roman Britain. London: Dent.

WEBSTER, J., 2003. Art as resistance and negotiation. In: S. SCOTT and J. WEBSTER, eds, Roman imperialism and provincial art. Cambridge: Cambridge University Press, pp. 24-51. 
WEINBROT, H.D. 1993. Britannia's issue. The rise of British literature from Dryden to Ossian.

Cambridge: Cambridge University Press.

WESSEX ARCHAEOLOGY, 2006. Withington Gloucestershire. Archaeological evaluation and assessment of results. Salisbury: Wessex Archaeology.

WHITEHEAD, C., 2009. Museums and the construction of disciplines. London: Duckworth.

WINCKELMANN, J., 1765. Reflections on the painting and sculpture of the Greeks. Transl. Henry Fuseli. London.

WINCKELMANN, J., 1767. Monumenti Antichi Inediti, Vol. 1. Roma.

WITTS, P., 2010. Mosaics in Roman Britain: Stories in stone. Stroud: Tempus.

YONGE, G., 1789. Introductory letter to the secretary. Archaeologia, 9, pp. 193-195. 